\title{
Assessing the Impact of Urbanization on Outdoor Thermal Comfort in Selected Local Government Areas in Ogun State, Nigeria
}

\author{
Akinbobola A. ${ }^{1, *}$ and Fafure T. ${ }^{2}$ \\ ${ }^{1,2}$ Department of Meteorology and Climate Science, School of Earth and Mineral Sciences, Federal University \\ of Technology, Akure, Ondo State, Nigeria \\ Corresponding Author: *aakinbobola@futa.edu.ng
}

https://doi.org/10.36263/nijest.2021.01.0243

\begin{abstract}
This study seeks to assess the land use land cover (LULC) and spatial-temporal trends of six outdoor thermal comfort indices in four Local Government Areas (LGAs) of Ogun state, Southwestern, Nigeria. Data used for this study are air temperature, relative humidity, cloud cover and wind speed which span from 1982 to 2018. These data were obtained from ERA-INTERIM archive. The 1986, 2000 and 2018 used for the analysis of the LULC were from the satellite imagery hosted by the United States Geological Survey (USGS). Landsat Thematic Mapper, Landsat 7 and Landsat 8 Operational Land Imager data of 1986, 2000 and 2018 to assess the changes that have taken place between these periods. Thermal comfort indices such as Effective Temperature (ET), Temperature Humidity Index (THI), Mean radiant temperature (MRT) and Relative Strain Index (RSI) were used. Rayman model was used for the computation of the three thermal comfort indices (MRT, PET, PMV). The results show decrease in vegetation, forest, and an increase in percentage of built-up areas between 1986-2000, and 2000-2018. A rapid increase in built-up areas in the three (Abeokuta South, Ifo, Shagamu,) of the four LGAs, while one (Ijebu East) has a slow increase in the built-up areas. The trend in the thermal comfort indices also shows that thermal discomfort had been on increase for the past 37 years and it was observed that the level of comfort has deteriorated more in the last decade compared to the previous decade especially in the built-up areas. This work suggests a framework for evaluating the relationship between the quantitative and qualitative parameters linking the microclimatic environment with subjective thermal assessment. This will contribute to the development of thermal comfort standards for outdoor urban settings. Also, the study will help urban planners in their decision making, and in heat forecast.
\end{abstract}

Keywords: Thermal comfort, Urbanization, Temperature, Urban space, Trends

\subsection{Introduction}

Urbanization in Nigeria, as in most developing countries, has been rapid, and the explosion of urban population has not been matched by a change in social, economic and technological development (United Nations Population Fund, 2007; WHO, 2011). Public infrastructure, social and health services have been neglected, and urban planning and zoning have been very slow or even stagnant in many cases (Eludoyin et al., 2013). Due to little or no climate responsive guidelines, sustaining outdoor life has been a serious issue in the tropics as urbanization increases rapidly (Ahmad, 2003). Also, the increasing urbanization of the subtropics is producing expanding urban areas with high density and a growing number of tall buildings $(\mathrm{Ng}, 2012)$. Comfort is more paramount to man, and that has brought about the study of thermal comfort over the years. The belief of thermal comfort came from the desire of man to be comfortable despite the climate (Eludoyin et al., 2013). Outside comfort zone lies the thermal stress (Ogunsote and Prucnal-Ogunsote, 2007). Studies have been made on thermal comfort since the 20th centuries, and it has brought improvements in which buildings are constructed, and also discoveries of air conditioning systems which aids comfortability in indoors even during the hottest and coldest climates. Outdoor thermal comfort is mainly about the physiology and also the heat balance of human body, which is commonly referred to as thermo-physiology (Höppe, 2002). 
The outdoor thermal comfort assessment focuses on estimating people's thermal sensation in outdoor environment by considering meteorological factors and individual activities. The results can be used to identify the high-risk area suffering from thermal stress in urban area and the valuable measures to mitigate harmful environment. Yang et al. (2019) concluded that urban land use and anthropogenic heat $(\mathrm{AH})$ emission can considerably influence the human thermal comfort during extreme heat events. In this study, a spatially heterogeneous AH emission data and updated urban land use data were integrated into the Weather Research and Forecasting model to simulate the physical processes of urban warming during summer. Simulations conducted in the Yangtze River Delta (YRD) of east China suggest that the mean urban heat island intensity reaches $1.49^{\circ} \mathrm{C}$ in urbanized areas during summer, with $\mathrm{AH}$ emission making a considerable contribution. The warming effect due to urban land use is intensified during extremely hot days, but in contrast, the AH effects are slightly reduced. Urban development increases the total thermal discomfort hours by $27 \%$ in the urban areas of YRD, with $\mathrm{AH}$ and urban land use contributing nearly equal amount. By limiting the daytime latent heat release, urban land use reduces the daily maximum heat stress particularly during extremely hot days; however, such alleviations can be offset by the AH emission. Strategies for mitigation of urban heat island effect and heat stress in cities should therefore include measures to reduce AH emission. Massetti et al. (2019) observed that more than half of the world population lives nowadays in urban areas and that's the reason why the quality of the urban environment has become a key issue for human health. In this context, it is important to estimate and document any action that contributes to improving thermal comfort and air quality.

Simulated results in Quang-Van et al. (2016) show that the increase in the surface air temperature is approximately $0.22{ }^{\circ} \mathrm{C}$ in the preexisting urbanized area and approximately $0.41^{\circ} \mathrm{C}$ in new highly urbanized areas. The rapid increase in global temperature has made outdoor thermal comfort an urgent topic (IPCC, 2007). It has been observed that there is a higher temperature in the urban growing areas compared to the rural areas, and that has made the assessment of thermal comfort in the urban areas more essential regarding the human health quality (Polydoros and Cartalis, 2014) for both indoor and outdoor environs. Galony (1996) revealed that temperature is non uniform across the perimeter of a city and it's largely dependent on land cover, location and the geometry of the city which are classified as local variables. Eludoyin et al. (2013) studied relative humidity, air temperature, thermal comfort and climate regionalization of Nigeria. The thermal comfort indices used such as THI, RSI, and effective temperature showed a contrasting result of thermal comfort for Nigeria due to variation in climate. Moreover, there was an observed increase in thermal stress from 2000 at most stations mostly in the north and south-western region.

This work seeks to assess the impact of urbanization on outdoor thermal comfort in selected Local Government Areas in Ogun state, by comparing trends in landuse/landcover with trends in temperature humidity index (THI), relative strain index (RSI), effective temperature index (ET), physiologically equivalent temperature (PET), and predicted mean vote (PMV).

\subsection{Materials and Methods}

\subsection{Study area}

The study areas as shown in Figure 1 are four selected local government areas in Ogun state, namely: Abeokuta South, Ifo, Shagamu, Ijebu East. Ogun State is considered to be one of the most developing areas in the southwest region of Nigeria because it shares boundary with Lagos State which is the main hub of activities. As a result of these developments, the four local government were selected, Abeokuta south, Ifo, and Shagamu local government areas plays a large part in this development while Ijebu east is known to be a rural area. 


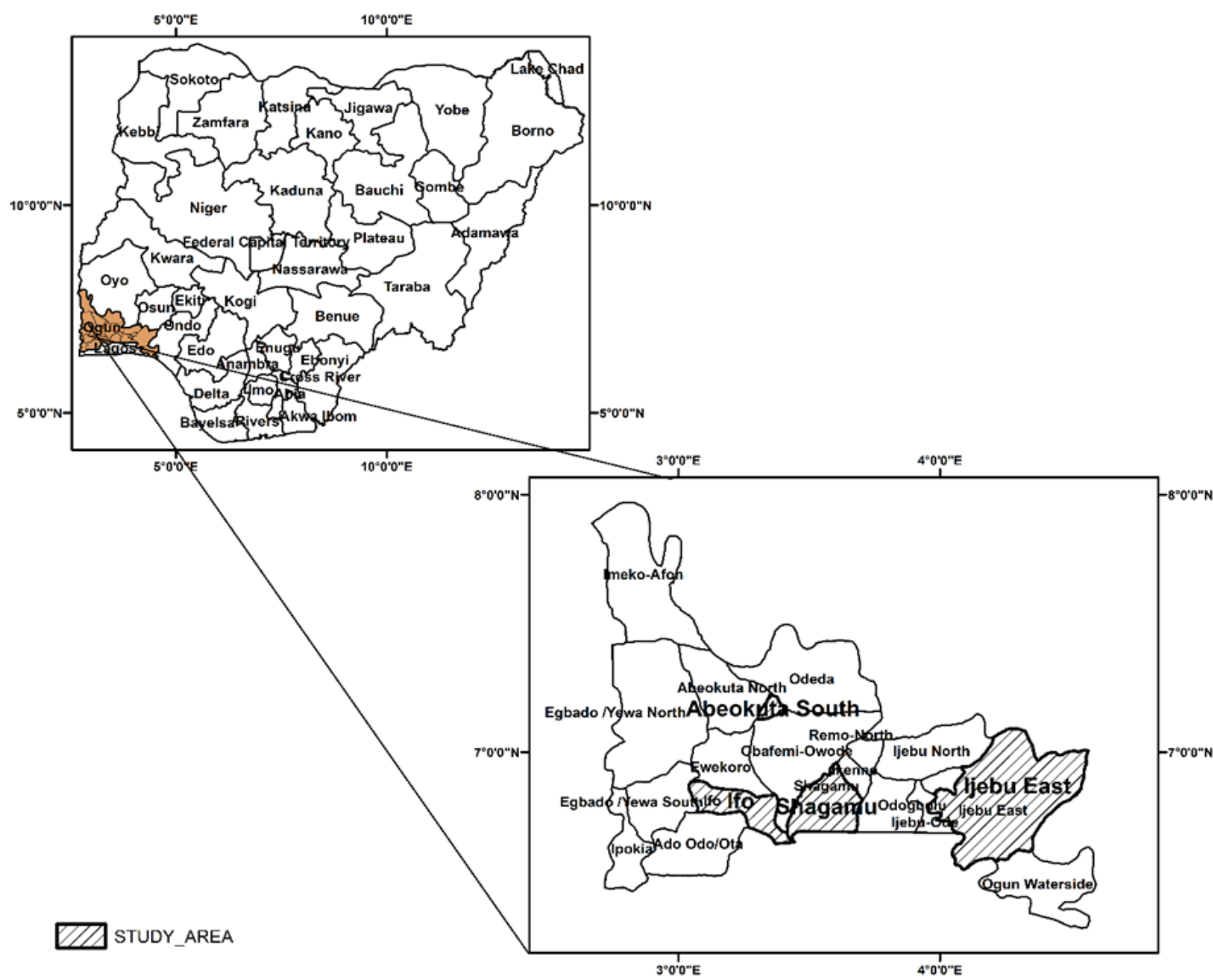

Figure 1: Maps showing location of the study area

2.1.1 Data acquisition

The research work used a gridded mean monthly data archived by ERA-INTERIM from the year 1982 to 2018 and this dataset includes the meteorological parameters needed for outdoor thermal comfort studies such as; relative humidity, air temperature, wind speed and cloud cover. Four LGAs (Abeokuta south, Ijebu east, Shagamu, Ifo) would be focused on in the study area. The LGAs can be classified under two categories; rural and urban. Ijebu east as rural, Abeokuta south, Ifo and Shagamu urban areas. What influenced the decision to use these four LGA classified into two, is for the comparison between the rural and urban area.

Rayman model was used in computing thermal comfort indices such as physiological equivalent temperature (PET), predicted mean vote (PMV) while effective temperature, relative strain index, and temperature humidity index were computed using a generally accepted formula for tropical regions. Outdoor thermal comfort indices like physiological equivalent temperature (PET) and predicted mean vote (PMV) asses thermal comfort in a thermo-physiological way, while Effective temperature (ET), relative strain index (RSI), and temperature humidity index (THI) does not. Figure 2 is the flowchart showing the procedure used in obtaining the data and methods used. 


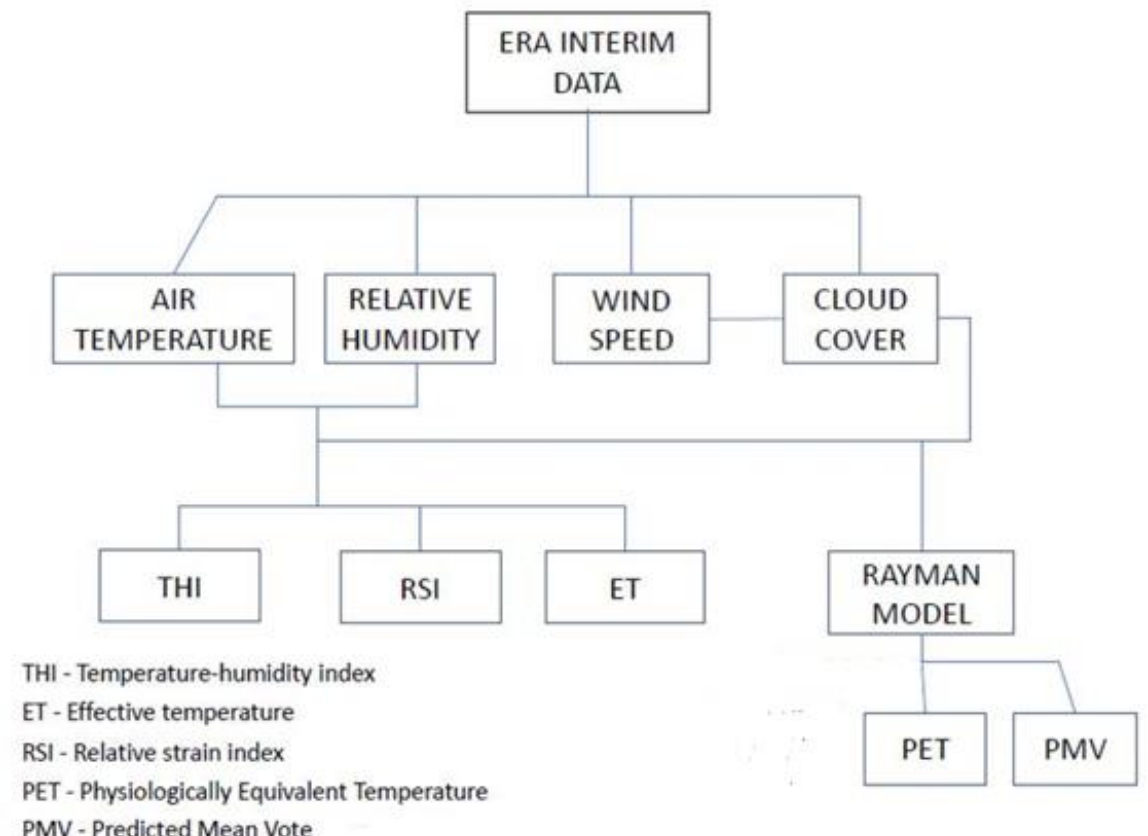

Figure 2: Flow chart showing how the data of each index were obtained

The formulae used in computing ET, THI, and RSI have been used by various researchers (Ayoade, 1978; Olaniran, 1982; Unger, 1999), and found to be valid and accepted for use in Nigeria and also in the tropics.

\subsection{Methods}

\subsubsection{Estimation of THI}

THI was estimated with the algorithm modified by (Nieuwolt, 1977) which is;

$T H I=0.8 T+\frac{R H \times T}{500}$

where; THI - is Temperature Humidity Index, T - is air temperature, RH - is Relative Humidity The categories of THI classification is given in Table 1.

Table 1: Thermal sensations with corresponding THI scale for Nigeria

\begin{tabular}{|l|l|}
\hline Thermal sensation & THI scale for Nigeria $\left({ }^{\circ} \mathrm{C}\right)$ \\
\hline Very cold & $<14$ \\
\hline Cold & $14-17$ \\
\hline Cool & $18-19.5$ \\
\hline Slightly Cool & $20-22$ \\
\hline Neutral & $23-24.6$ \\
\hline Slightly warm & $24.7-27$ \\
\hline Warm & $28-30$ \\
\hline
\end{tabular}

Source: (Ogunsote, 2003; Olaniran, 1982; Ayoade, 1978; Markus and Morris, 1980; Omonijo and Matzarakis, 2011).

\subsubsection{Estimation of RSI}

RSI was estimated with the algorithm;

$R S I=\frac{[10.74+0.74+(T-35)]}{44-0.0075(\text { RH.es })}$

where RH - Is Relative Humidity, T - Is the Air Temperature, es - saturated vapour pressure.

The classification of RSI developed by (Kyle, 1992) is presented in Table 2. 
Table 2: RSI classification

\begin{tabular}{|l|l|}
\hline RSI & Proportion of persons unstressed/distressed (\%) \\
\hline 0.10 & 100 unstressed \\
\hline 0.20 & 75 unstressed \\
\hline 0.30 & 0 unstressed \\
\hline 0.40 & 75 stressed \\
\hline 0.50 & 100 stressed \\
\hline
\end{tabular}

Source: (Kyle, 1992)

\subsubsection{Estimation of ET}

ET was estimated using the equation shown below:

$E T=T-0.4(T-10)\left(1-\frac{R H}{100}\right)$

where $\mathrm{T}$ - Is the Air Temperature, RH - Is the Relative Humidity.

Table 3 shows the effective temperature scale which gives the ranges of temperature for thermal sensation.

Table 3: Thermal sensations with corresponding ET scale

\begin{tabular}{|l|l|}
\hline ET scale $\left({ }^{\circ} \mathrm{C}\right)$ & Thermal sensation \\
\hline$<18.9$ & Cold Stress \\
\hline $18.9-25.6$ & Comfortable \\
\hline 25.6 & Heat Stress \\
\hline
\end{tabular}

Source: (Eludoyin et al., 2013).

\subsubsection{Estimation of PET and PMV}

Matzarakis et al. (2007) developed Rayman model, an urban climate model which has been used for several studies on urban climate. This model was used in estimating PET and PMV. The comfort scale is presented in Table 4.

Table 4: PMV comfort scale

\begin{tabular}{|l|l|}
\hline PMV values & Human sensations \\
\hline-3 & Cold \\
\hline-2 & Cool \\
\hline-1 & Slightly cool \\
\hline 0 & Neutral (comfort) \\
\hline+1 & Slightly warm \\
\hline+2 & Warm \\
\hline+3 & Hot \\
\hline
\end{tabular}

Source: Given by the American Society of heating, refrigerating, and air conditioning engineers, Inc (ASHRAE).

The PET comfort scale is presented in Table 5.

Table 5: PET comfort scale

\begin{tabular}{|l|l|}
\hline Thermal sensation & PET range for Nigeria $\left({ }^{\circ} \mathrm{C}\right)$ \\
\hline Very cold & $<11$ \\
\hline Cold & $11-15$ \\
\hline Cool & $16-19$ \\
\hline Slightly cool & $20-23$ \\
\hline Neutral & $24-27$ \\
\hline Slightly warm & $28-31$ \\
\hline Warm & $32-36$ \\
\hline Hot & $37-42$ \\
\hline Very hot & $>42$ \\
\hline
\end{tabular}

Source: Given by the American Society of heating, refrigerating, and air conditioning engineers, Inc (ASHRAE).

2.2.5 Land use change 
The satellite imagery for 1982, 2001 and 2018 were used. This selection was made considering the availability of a cloud free imagery in the study between 1982 and 1999 and other factors like scar line error found in Landsat 7, otherwise the interval would have been regular.

Imagery for the selected years were classified into urban areas (this includes industrial, commercial, residential and non-vegetated area), forest, vegetation's (Thick bushes, farm lands, non-forest), and water bodies (lakes, rivers and ponds) using supervised method of classification.

Field calculator was used in calculating the counts of the classified divisions into hectares.

$$
\text { Hectares }=\frac{(\text { Count } \times \text { Square of Cell size of classified image })}{10000}
$$

\subsection{Results and Discussion}

\subsection{Land use}

Figures 3(a-d), 4(a-d) and 5(a-d) show the land use trend in Abeokuta south, Ifo, Shagamu, and Ijebu east in 1986, 2000 and 2018 respectively. In these figures, it was observed that there is a significant deterioration of vegetation and forests from 1986 to 2018, while the urban areas keep expanding.

This Figure 3(a-d) revealed the percentage covered by different classes of LULC in 1986. In 1986 LULC of Abeokuta south shows that 55\% of the land area was covered with vegetation, while $39 \%$ of the land area was urban and the remaining $6 \%$ were areas covered with forest. That of Ifo showed that $68 \%$ of land area was covered with forest, while built-up areas and vegetation takes $7 \%$ and $25 \%$ respectively. Shagamu LULC revealed that forest covered up to $22 \%$ of the land, while vegetation took up to $73 \%$; the built-up area covered just $5 \%$ of the land area. Ijebu east has little or no water body, $74 \%$ of Ijebu east land area was covered with forest, vegetation takes $25 \%$ and built-up areas covered $1 \%$ of the area.

LULC of the four LGAs in 2000 is represented in Figure 4(a-d). It was observed in the figure that Abeokuta south had a slight decrease in the percentage of vegetation that covers the land area (vegetation $-54 \%$ ), built-up area and forest still maintains $39 \%$ and $6 \%$ respectively. There was a notable addition of water body, which might have been covered by vegetation in Figure 3(a) representing 1986 LULC. Water body takes $1 \%$ of the land area.

Ifo in 2000 as shown in Figure 4(a-d) has a 2\% reduction from 1986 LULC in the amount of vegetation that covered the area (vegetation 66\%). Built-up areas increased to $12 \%$ from $7 \%$ while forest reduced to $22 \%$ from $25 \%$. Shagamu has $0 \%$ of vegetation, forest covered $92 \%$ of the land and remaining 8\% were fuilt-up areas. No notable change in the LULC of Ijebu east from 1986 to 2000. Forest maintains $74 \%$, vegetation $25 \%$, and built-up areas $1 \%$.

In Figure 5(a-d) there was a drastic change in LULC for most of the LGAs when compared to 1986 and 2000 LULC. Abeokuta south land area in the figure was observed to be covered by $93 \%$ built-up areas, $1 \%$ forest and $6 \%$ vegetation. Ifo land area increased in number of built-up areas to $37 \%$, the amount of forest reduced to $45 \%$, and the amount of vegetation in the area also decreased to $18 \%$ LULC of Shagamu in 2018, showed the amount of forest in the area increased to $58 \%$ from $22 \%$ in year 2000. Vegetation also reduced drastically to $17 \%$, while $25 \%$ of built-up area was observed, which is a large increase from the 5\% it was in 2000. Ijebu east LULC shows a noticeable increase in the amount of forest covering the area (forest $-85 \%$ ), $14 \%$ of the area were covered by vegetation, while $1 \%$ of built-up area was still maintained.

The increase in built up areas and deterioration in other classes such as (vegetation, forest and water bodies) shows that there is an increase in the level of urbanization in the four LGAs and Njoroge et al. (2011) already showed that land use related to human activities such as built areas increased to the detriment of wetland and vegetated areas, which signifies the city's growth. A rapid increase in builtup areas were observed in Ifo and Abeokuta south LGAs, while Ijebu east LGA has a slow increase in the built-up areas. A rapid increase in urbanization was however expected in Abeokuta south which is the capital of Ogun state. 


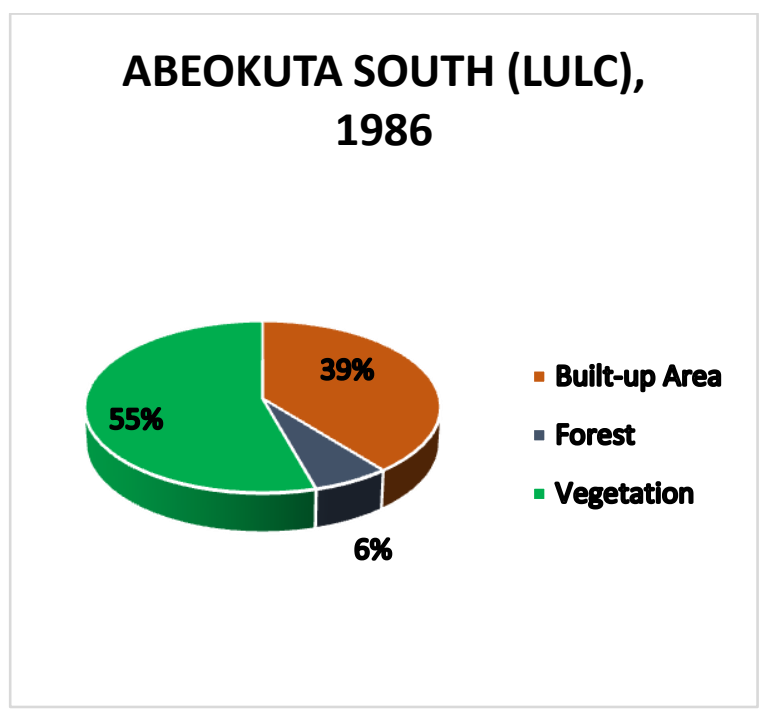

(a)

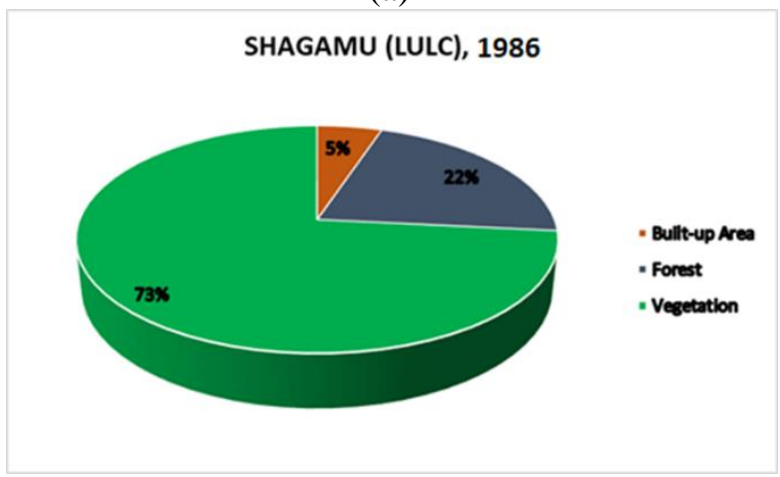

(c)

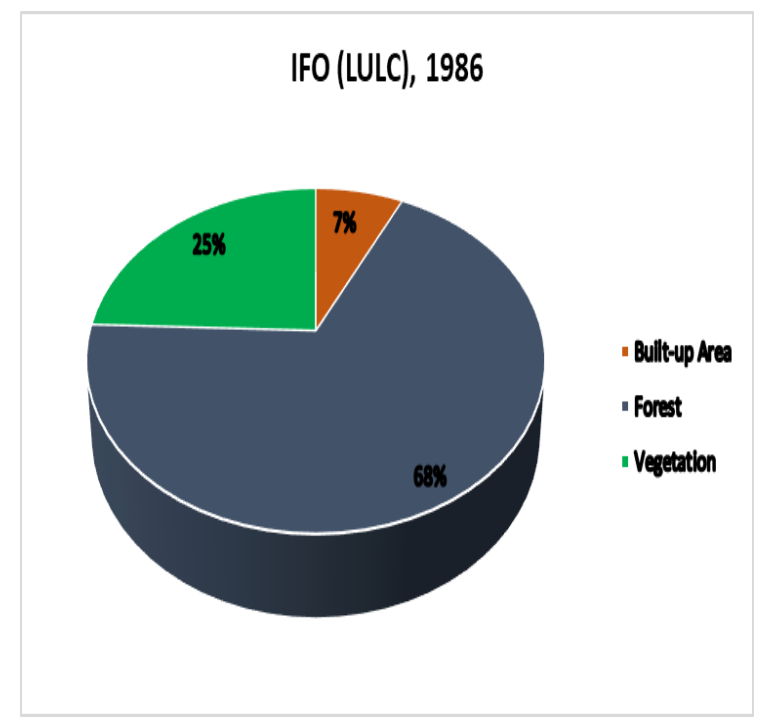

(b)

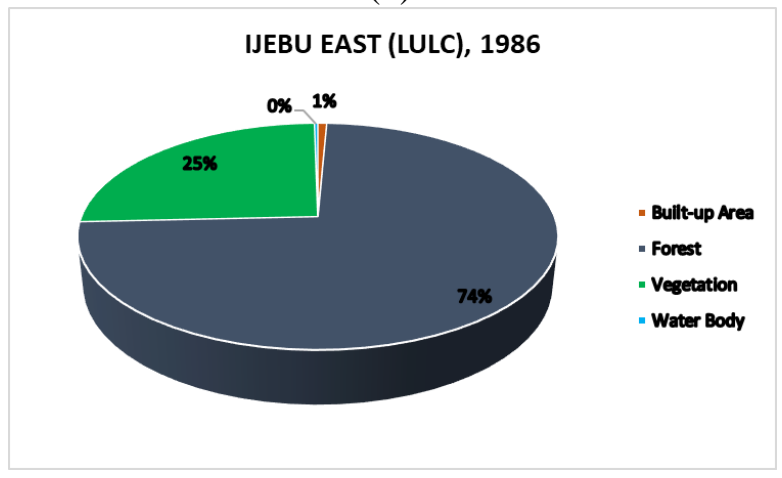

(d)

Figure 3(a-d): Pie chart showing the percentage covered by different class of LULC in 1986

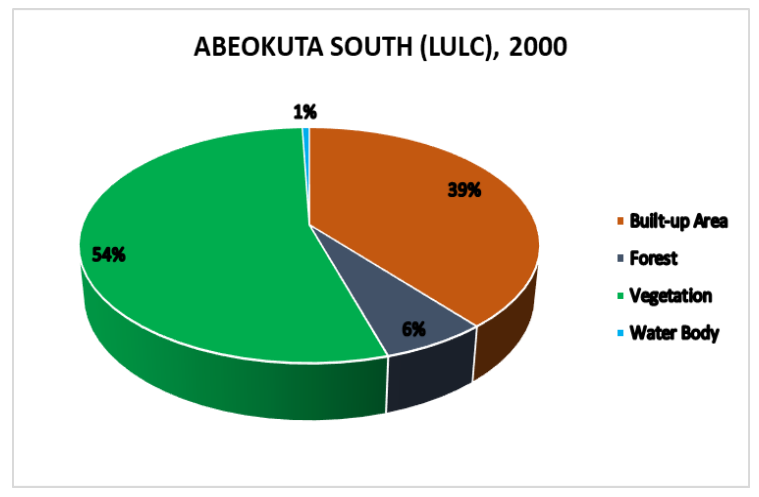

(a)

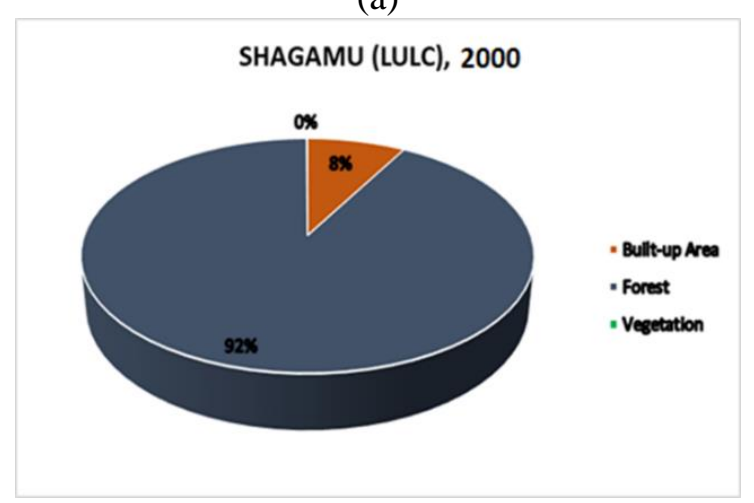

(c)

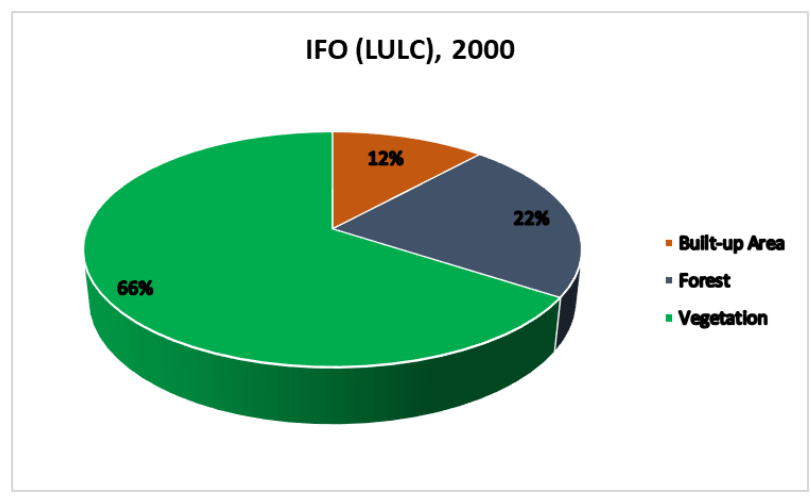

(b)

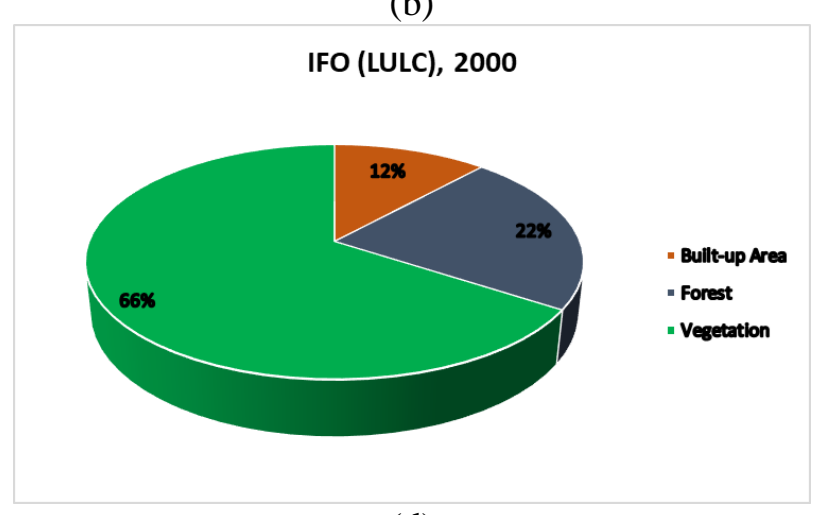

(d)

Figure 4(a-d): Pie chart showing the percentage covered by different class of LULC in 2000 


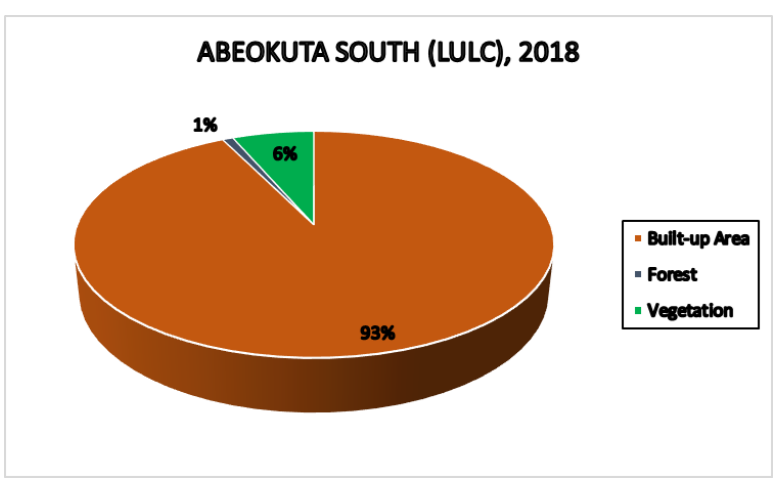

(a)

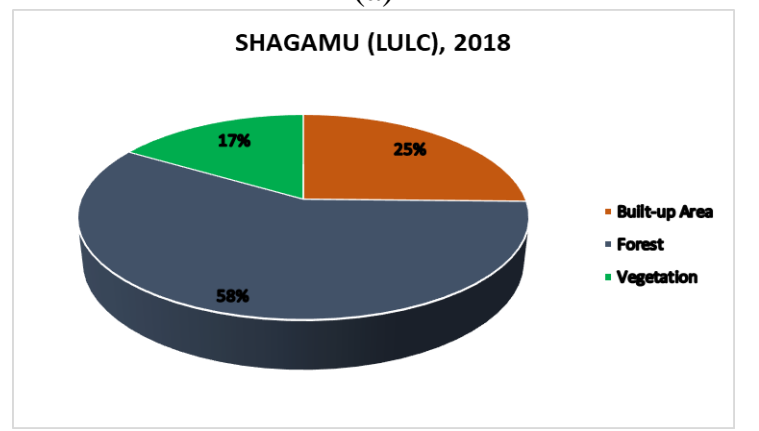

(c)

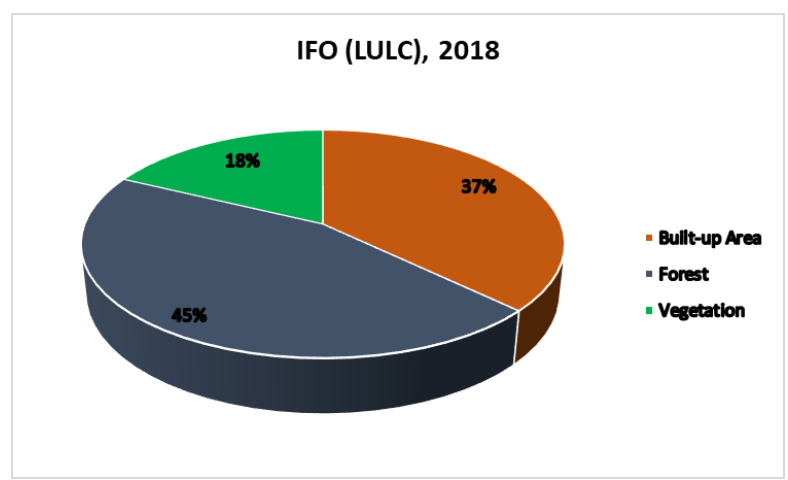

(b)

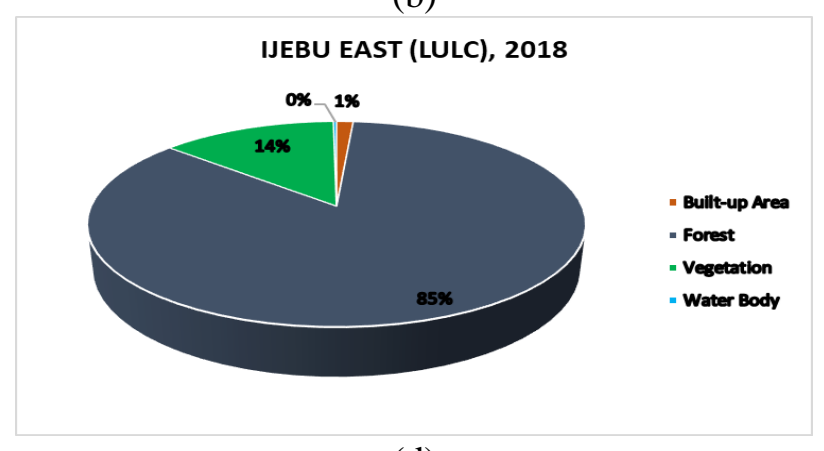

(d)

Figure 5(a-d): Pie chart showing the percentage covered by different class of LULC in 2018

\subsection{Annual trends of estimated thermal conditions}

Figure 6(a-e) shows the annual trends of AT, THI, PET, ET, RSI, PMV. Figure 6a shows the annual trends of estimated THI values, it can be observed that the highest value for THI in Abeokuta South, Ifo, Ijebu east were seen in 2010 (26.51, 26.65, 26.28 respectively) and Shagamu had its highest value both in 2010 and 2016 (26.58), while the lowest THI occurred in 1992 (Ifo 25.24, Ijebu East 24.69, Shagamu 25.07) except for Abeokuta South that has its lowest in 1989 which is 25. The figure showed increase in the trend of THI from 1982 to 2018 in all the LGAs; study from (Eludoyin et al., 2013) shows that there was an increase in the value of THI in the tropical rain forest in region of Nigeria, which means an increase in the level of discomfort.

According to the THI classification used by (Omonijo and Matzarakis, 2011), the THI estimated values in the areas studied can be observed to be comfortable from 1982, and the level of discomfort significantly increased over the years. Despite the increase in the discomfort level THI value hasn't gone beyond the slightly warm THI classification level, however, some very close values to the upper limit of slightly warm level were noted.

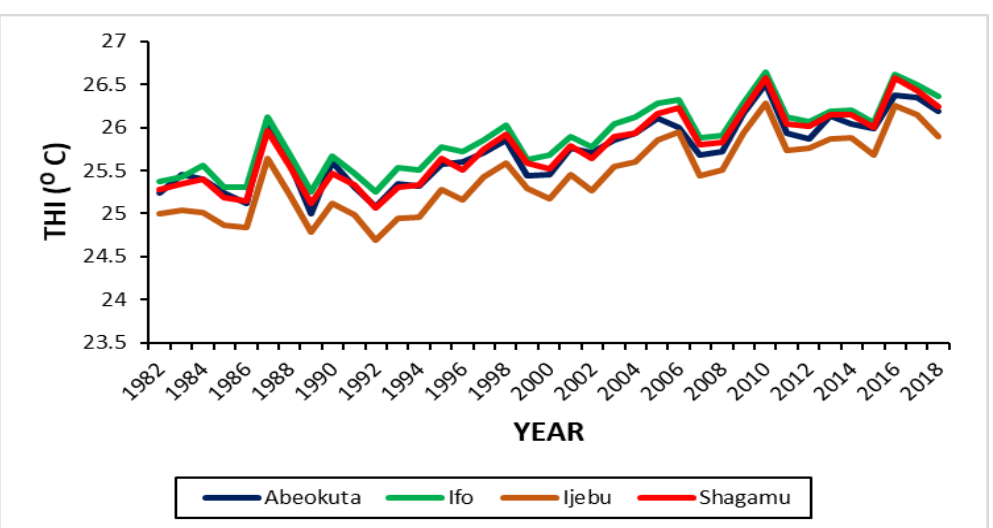

Figure 6a: Annual trends of estimated THI values from 1982-2018

Figure $6 \mathrm{~b}$ shows the trends of RSI values in the stations; the RSI values from 1982 to 2018 drastically increased, which means the level of thermal discomfort are on the rise in these areas. Abeokuta South and Shagamu have their least RSI values in 1989 (0.089 and 0.091 respectively) while Ifo and Ijebu 
east had the least RSI values in 1992 (0.099 and 0.073 respectively). The peak RSI values for all the areas were in 2010 (Abeokuta South -0.157 , Ifo - 0.164, Ijebu east -0.146 , Shagamu - 0.160). The Kyle RSI classification (1992) shows that above $75 \%$ of people in the study area feels unstressed.

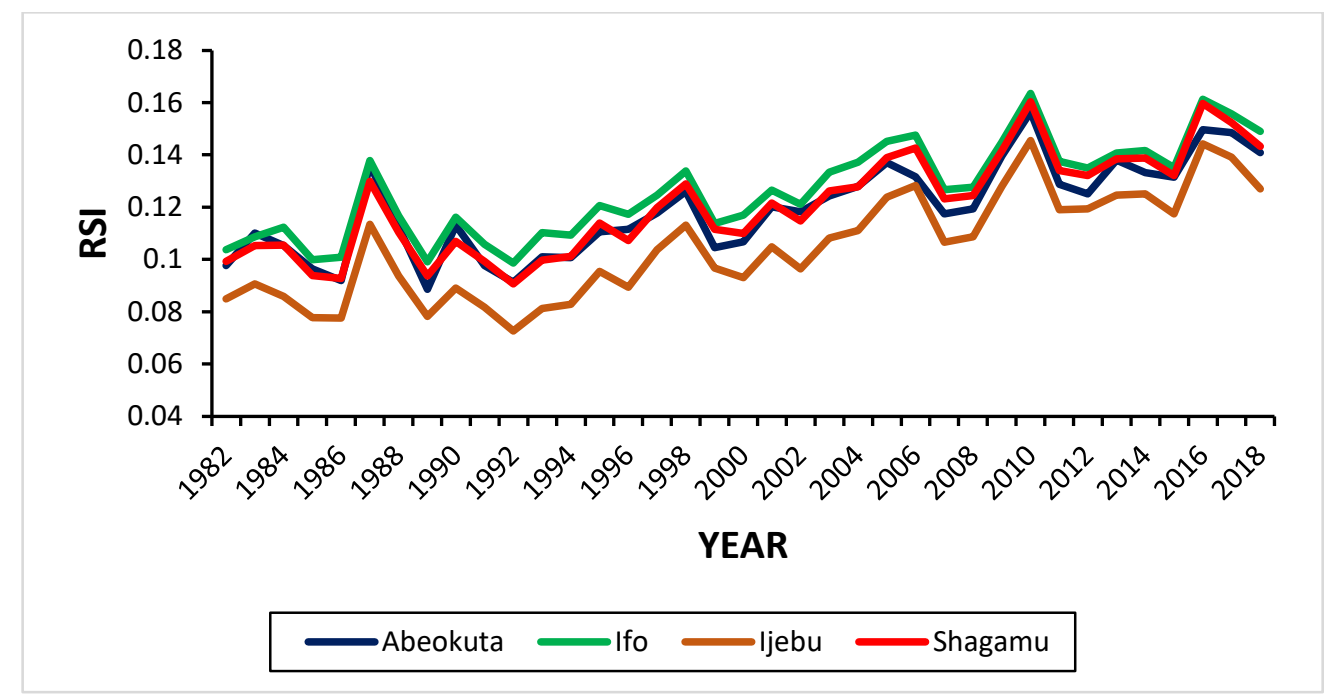

Figure 6b: Annual trends of estimated RSI values from 1982-2018

From the annual trends of PMV values in Figure $6 c$, it can be observed that there is an increase in thermal discomfort over the years. Based on PMV classification Ifo LGA exceeded the neutral (comfort) level all through the years (1982 - 2018), Abeokuta south and Shagamu had in one occasion recorded a PMV value at neutral level, while Ijebu east recorded PMV at neutral level in several occasions.

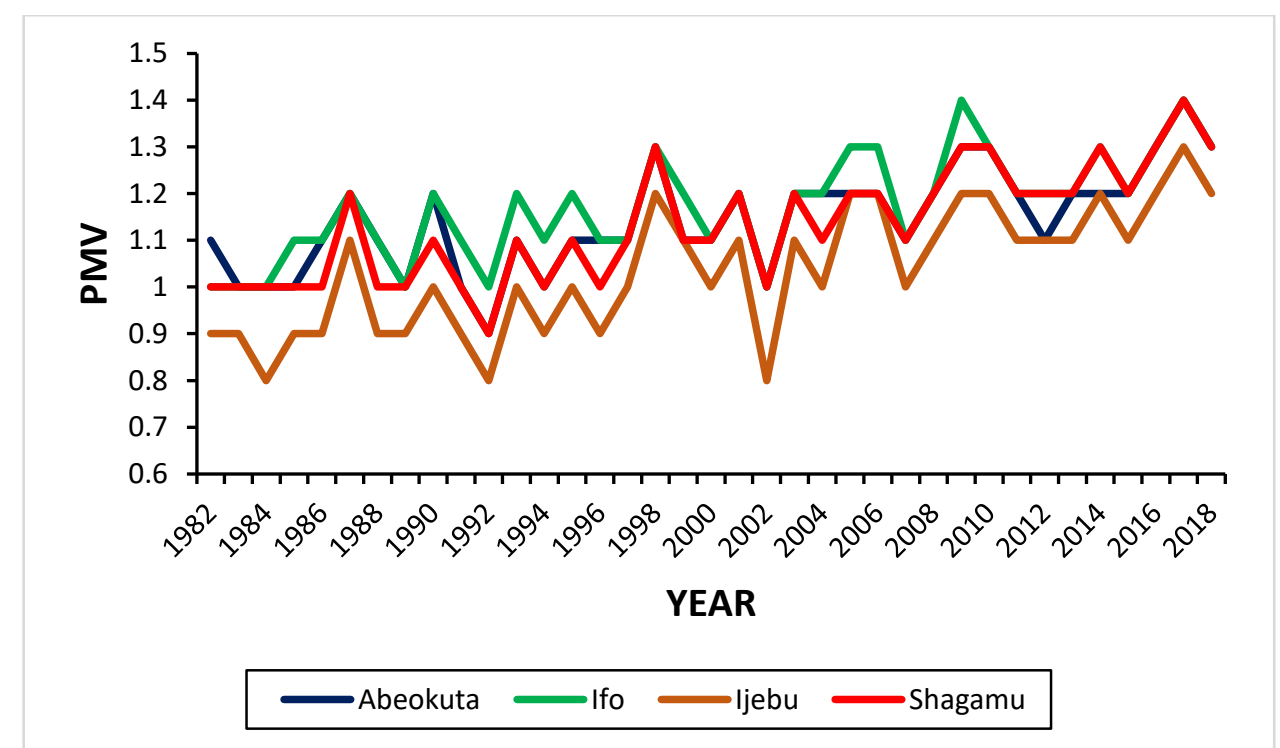

Figure 6c: Annual trends of estimated PMV values from 1982 - 2018

The annual trends of the PET value in the study area are shown in Figure 6d. The PET values of these areas can be categorized under slightly cool and neutral based on PET classification given by the American Society of heating, refrigerating, and air conditioning engineers, Inc (ASHRAE). Ijebu east PET values range from slight cool to neutral thermal conditions, while neutral conditions dominate all through (1982 - 2018) in Abeokuta south, Ifo, and Shagamu. 


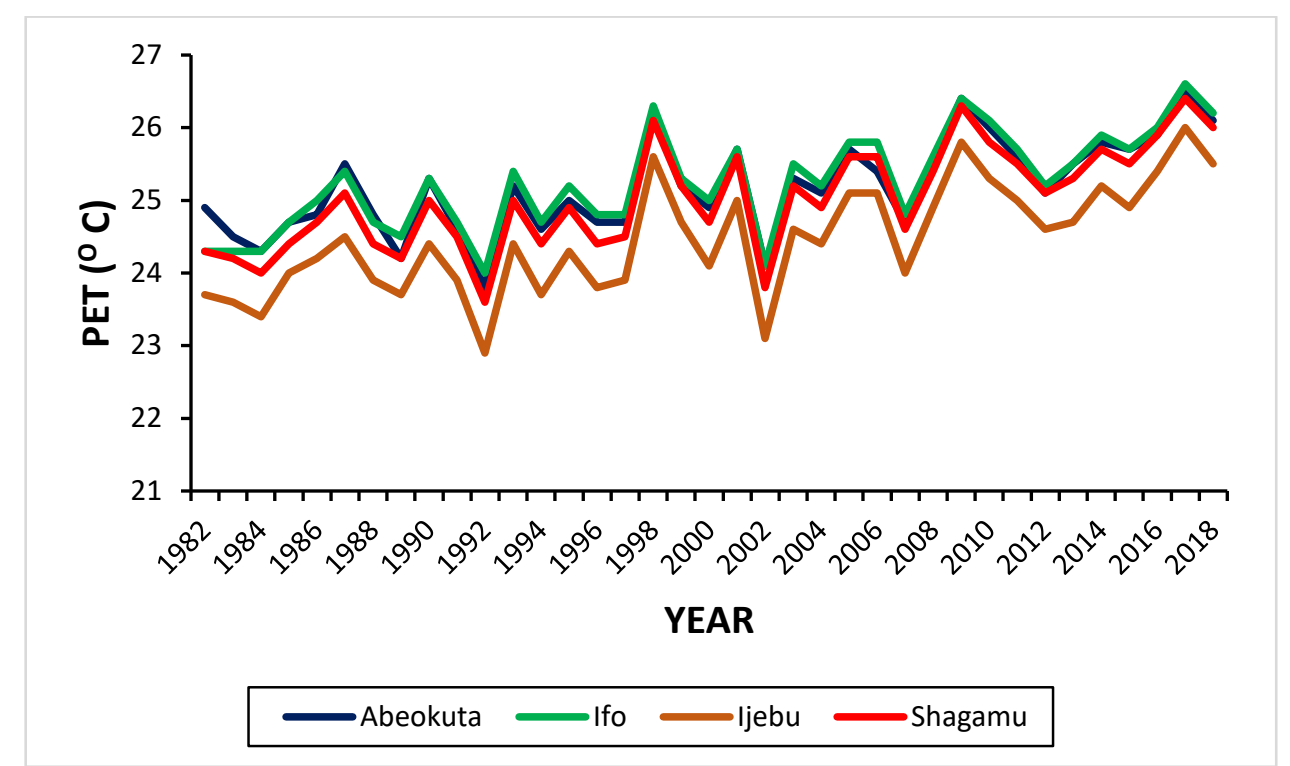

Figure 6d: Annual trends of estimated PET values from $1982-2018$

The annual trend of effective temperature (ET) is shown in Figure 6e. The four LGAs all have their peak in 2010 (Abeokuta south - 26.29, Ifo - 26.43, Ijebu - 26.11, Shagamu - 26.37), while the least values of ET were found in 1992, except for Abeokuta south that has it's least ET value in 1989; Abeokuta south -24.80 , Ifo -25.04 , Ijebu -24.53 , Shagamu - 24.87. Using the ET classification by (Eludoyin et al., 2013), it can be deduced that the comfortability state of the four LGAs in the first decade has deteriorated, and the heat stress of this areas are on the rise.

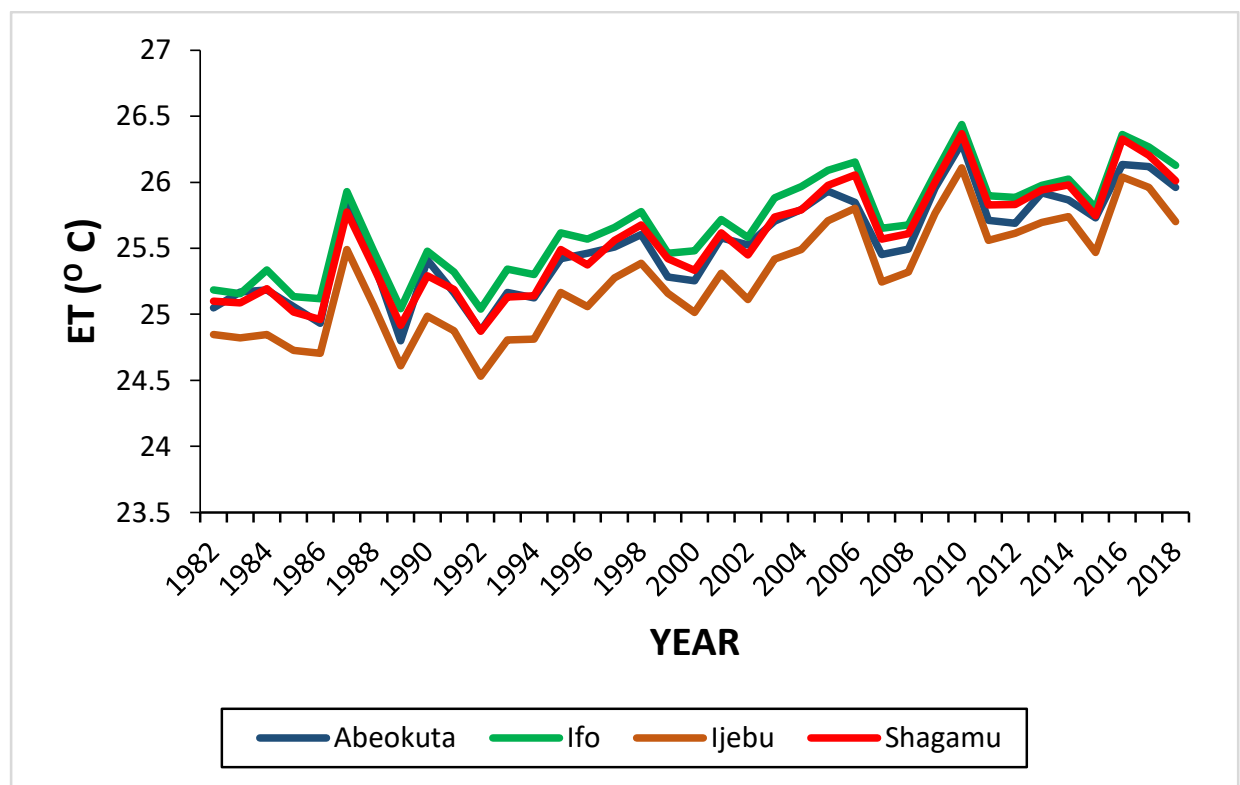

Figure 6e: Annual trends of estimated ET values from $1982-2018$

The coefficient of determination for THI, ET, RSI in the four local government is above $50 \%$ and it implies that there is a high chance for the increase trend to continue with time. Coefficient of determination for PMV and PET values in Ifo, Shagamu, and Ijebu east are above 50\%, thus a higher chance for continuous increase in the trend; Abeokuta South PMV and PET value is slightly below $50 \%$. Coefficient of determination for MRT in the four LGAs is considerably low compared to the other five thermal comfort indices. Five out of the six thermal comfort indices in the four local government areas shows the rate at which thermal discomfort is increasing with time.

From the plots (Figure 6a-e), similar trend patterns were observed. The annual trends depict that thermal discomfort had been on the increase for the past 37 years and it could be observed that the level of thermal comfort has deteriorated more in the last decade compared to the previous decades. 
Ifo LGA appears to be the most thermally discomfort in all the four LGAs, while Ijebu East LGA is the most thermally comfortable.

\subsection{Spatial variations of estimated thermal conditions}

The spatial variations of the estimated mean of different thermal conditions (THI, RSI, PMV, PET, ET) from $1982-2018$ are shown in the Figure 7(a-f).

Figure 7a shows the spatial variation of THI mean value from 1982 - 2018. From the figure, the four LGAs thermal condition can be categorized under slightly warm condition based on THI classification (Omonijo and Matzarakis, 2011). Discomfort condition was more pronounced in Ifo while Ijebu east has the lowest level of thermal discomfort. Figure $7 \mathrm{~b}$ which is the estimated RSI mean values shows that the study areas fall within RSI categories of $100 \%$ of persons who feel unstressed and $75 \%$ of persons who feel unstressed. The level of thermal discomfort was also noticed to be higher in Ifo and lesser in Ijebu east.

Figure 7c represents the estimated PMV mean values; it also shows similar observations classifying the areas under slightly warm categories. With Ijebu east having a less thermal discomfort condition compared to the other LGA and Ifo has the highest discomfort level. Abeokuta south appear to be in a higher level of discomfort than Shagamu.

From Figure $7 \mathrm{~d}$ showing the PET mean value, it can be observed that the four LGAs falls under the neutral category. The estimated effective temperature mean value from $1982-2018$ presented in Figure 7e shows that Ifo and Shagamu can be classified under the heat stress level based on the ET classification by (Eludoyin et al., 2013), while Ijebu East and Abeokuta South seats at the upper limit of the comfortability level of ET.

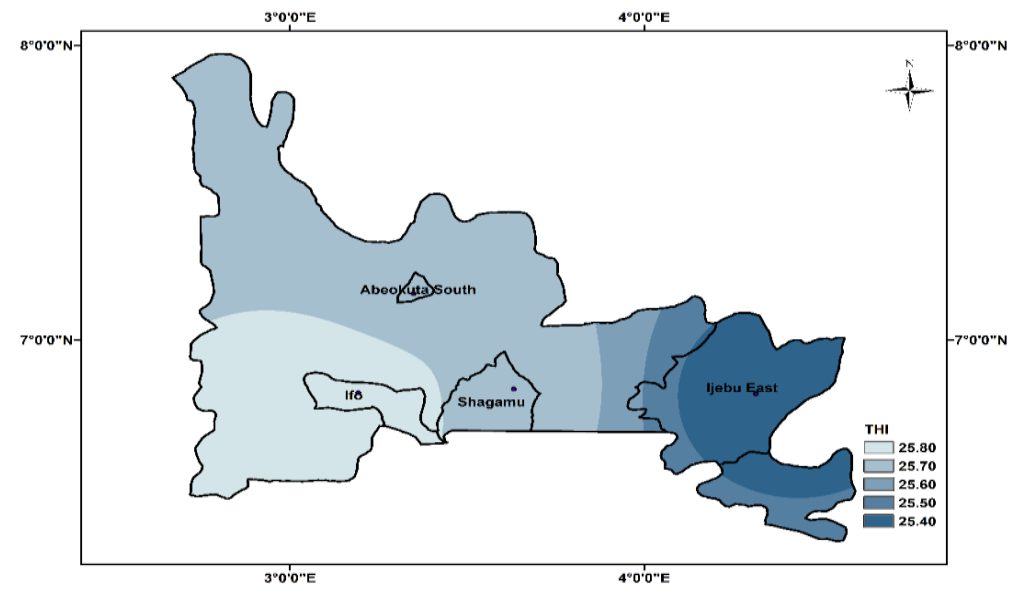

Figure 7a: Spatial variation of estimated THI mean value for the period $1982-2018$

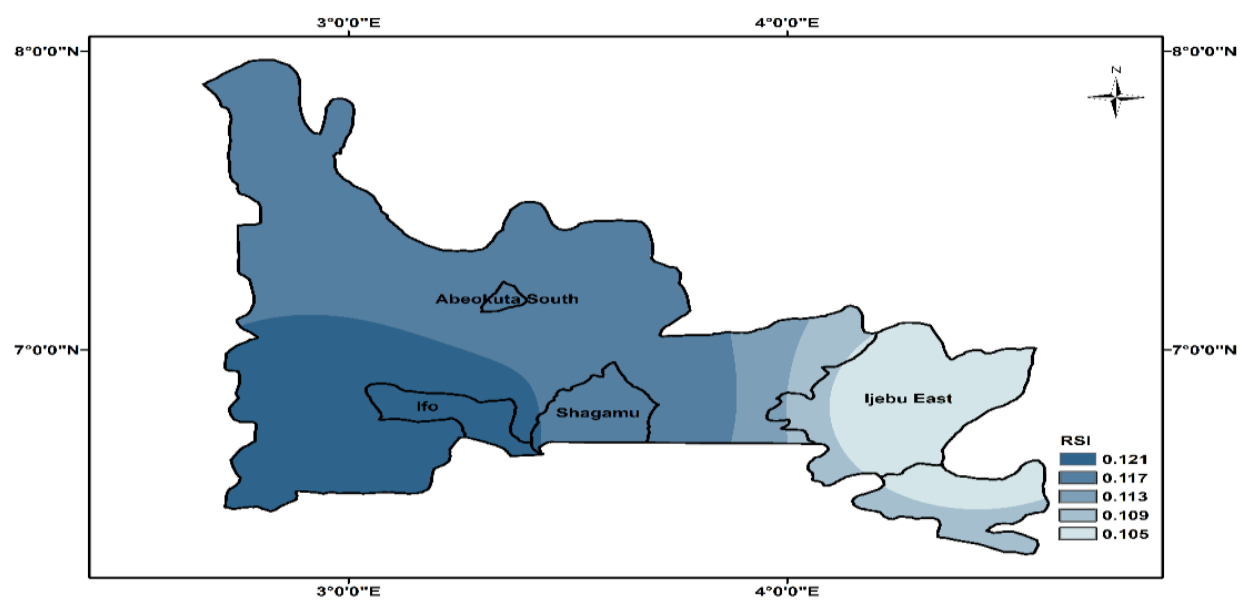

Figure 7b: Spatial variation of estimated RSI mean value for the period $1982-2018$ 


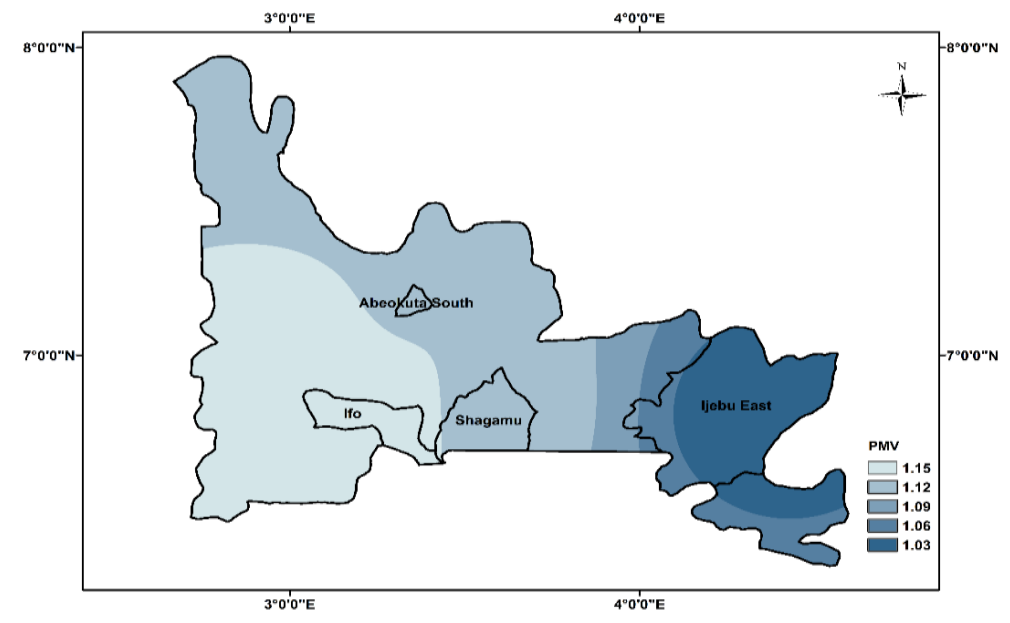

Figure 7c: Spatial variation of estimated PMV mean value for the period $1982-2018$

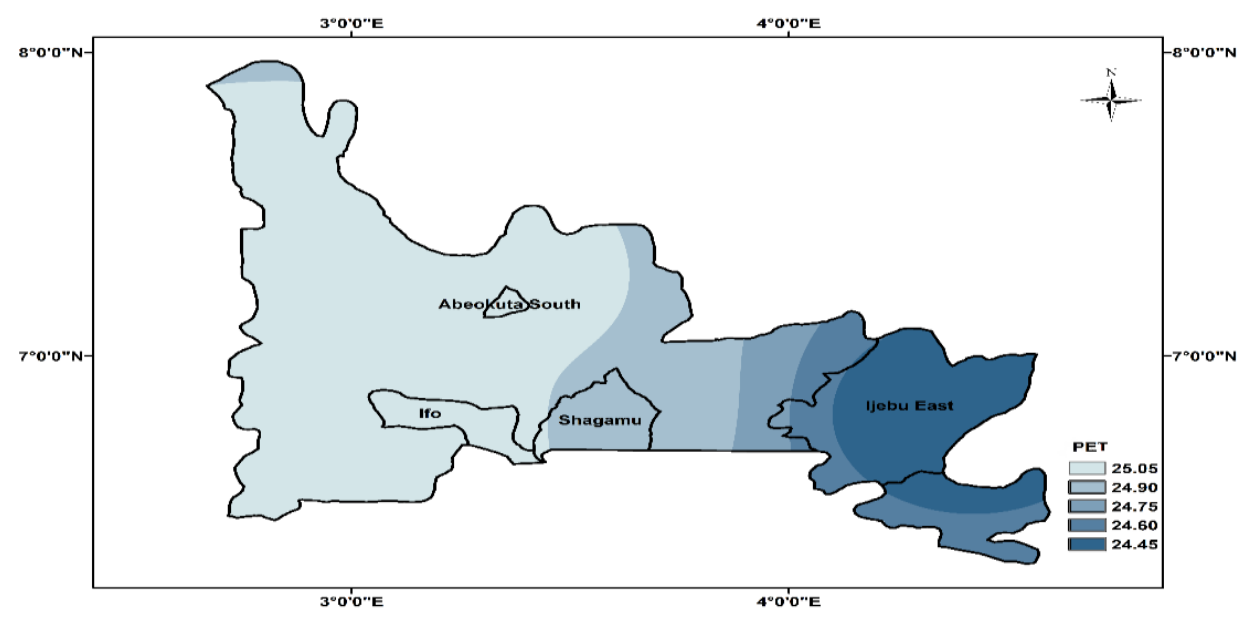

Figure 7d: Spatial variation of estimated PET mean value for the period $1982-2018$

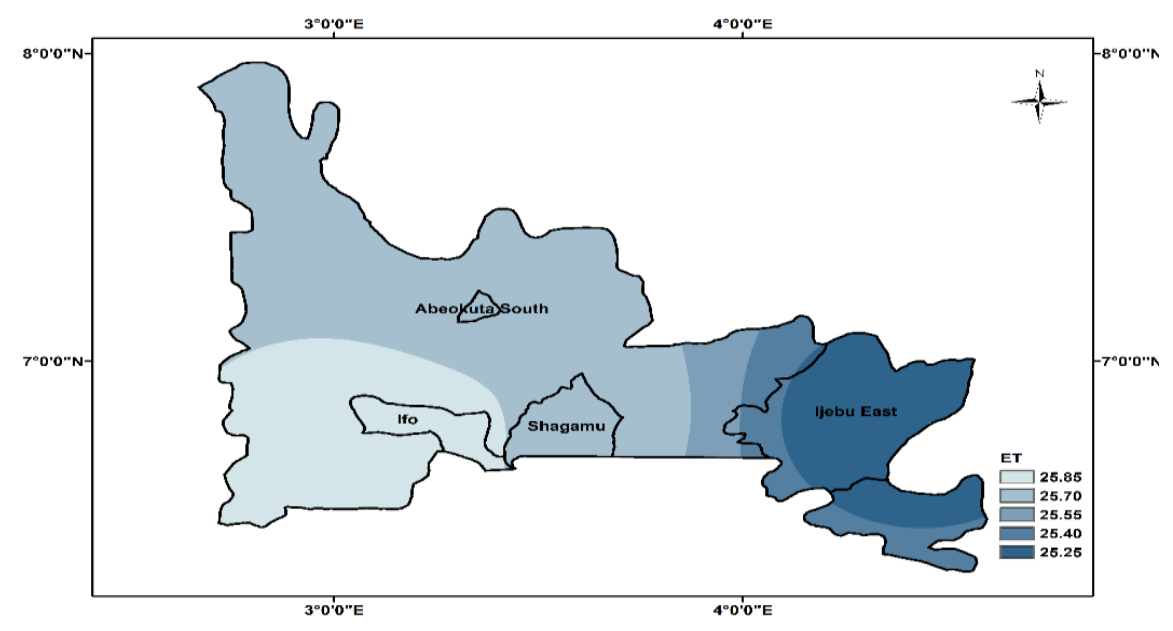

Figure 7e: Spatial variation of estimated ET mean value for the period $1982-2018$ 


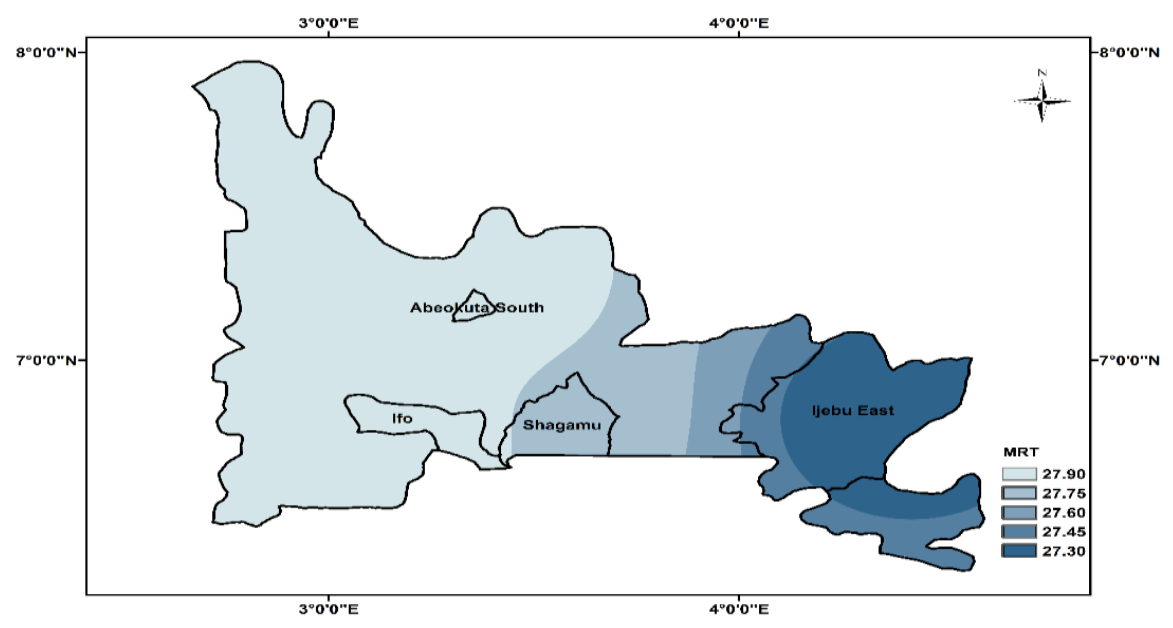

Figure 7f: Spatial variation of estimated MRT mean value for the period $1982-2018$

\subsection{Thermal comfort and Land Use/Land Cover}

Figure (8a-p) show the trends of Air temperature and thermal indices along with the built-up areas within 1986 to 2018 in each LGAs, while Table 6 to 11 showed the percentage change of the built-up areas within 1986 to 2000 and 2000 to 2018. The built-up areas in Abeokuta south took as much as 2785 hectares in 1986; it later increased with $37.4 \%$ to 3826 hectares, and by 2018 it expanded by $72 \%$ to 6579 hectares. In 1986, built-up areas covered 3801 hectares in Ifo and by 2000 it increased by $62 \%$ to 6156 hectares; the built-up areas expanded drastically in 2018 by $214.3 \%$ (19351 hectares in 2018). Shagamu built-up areas increased by $60.9 \%$ from 3157 hectares in 1986 to 5079 hectares in 2000, and then further increased by $206.2 \%$ to 15554 hectares in 2018. Ijebu east recorded 1579 hectares covered with built-up areas in 1986, with $62 \%$ change from 1986 to 2000 it expanded to 2724 hectares and by 2018 it has expanded to 2843 , which is only $4.4 \%$ increase from 2000 .

It can be observed also from the figures that air temperature and the estimated thermal indices increases along with increase in Built-up areas from 1986 to 2018. Similar studies show that urbanization or more impervious surfaces have result to rising temperature in urban areas. (Silva $e t$ al., 2018) found that rapid urbanization in Paçodo Lumiar County, Brazil had a significant impact on its surface temperature, which result to $5.3^{\circ} \mathrm{C}$ increase in urban surface temperature within 1988 and 2014 (a warming trend of $2.03^{\circ} \mathrm{C} /$ decade), due to the result of the increase in the areas of impervious surfaces. Xiong et al. (2012) studied the urbanization impact in the urban climate of Guangzhou, South China showed that the highest increase in temperature anomalies was strongly associated with built-up areas. There were some exception; MRT in the four LGAs, had a lesser value in year 2000 compared to that of year 1986, but then, it increases to a higher value in 2018. Abeokuta south and Ifo LGAs maintained the same value of PMV in 1986 and 2000.

It can also be observed that among the four LGAs Ijebu east has the lowest urban development rate and it appears to be the area with the least thermal discomfort, while Ifo appears to be the highest both in urban development rate and thermal discomfort level. However, environmental development as studied by (Unger, 1999); can cause disruption of wind flow and air turbulence by built-up areas, alteration of natural radiation balance, upset of water vapour balance due to change of moist surfaces and the emission of artificial heat, water vapour through combustion processes. There has being an increase in commerce and industry with the human population, and the impacts on local climate cannot be overemphasized with 'heat islands' in many of the towns (Omogbai, 1985; Aina, 1989; Oniarah, 1990; Adebayo, 1991; Efe, 2004; Adelekan, 2005; Akinbode et al., 2008). Robaa (2011) investigated the effect of urbanization on outdoor thermal human comfort in greater Cairo region. The study showed that urbanization plays a major role in the increase of human hot uncomfortable feeling, which limits human activities in the urban area, whereas the rural conditions lead to optimum weather comfort for further and more human activities. 
Table 6: Built-up areas in Abeokuta south and Ifo and its percentage change within 1986 to 2018

\begin{tabular}{|l|l|l|l|l|}
\hline Year & $\begin{array}{l}\text { Built-up Areas in } \\
\text { Abeokuta Sercentage Change } \\
\text { (hectares) }\end{array}$ & $\begin{array}{l}\text { Built-up Areas in Ifo } \\
(\%)\end{array}$ & $\begin{array}{l}\text { Percentage Change } \\
(\%)\end{array}$ \\
\hline 1986 & 2785 & 37.4 & 3801 & 62 \\
\hline 2000 & 3826 & 72 & 6156 & 214.3 \\
\hline 2018 & 6579 & 726351 & 1931 \\
\hline
\end{tabular}

Table 7: Built-up areas in Shagamu and Ijebu East $\left({ }^{\circ} \mathrm{C}\right)$ and its percentage change within 1986 to 2018

\begin{tabular}{|l|l|l|l|l|}
\hline Year & $\begin{array}{l}\text { Built-up Areas in } \\
\text { Shagamu (hectares) }\end{array}$ & $\begin{array}{l}\text { Percentage Change } \\
(\%)\end{array}$ & $\begin{array}{l}\text { Built-up Areas in } \\
\text { jjebu East } \\
\text { (hectares) }\end{array}$ & $\begin{array}{l}\text { Percentage Change } \\
(\%)\end{array}$ \\
\hline 1986 & 3157 & 60.9 & 1579 & 72.5 \\
\hline 2000 & 5079 & 2724 & 4.4 \\
\hline 2018 & 15554 & 206.2 & 2843 & \\
\hline
\end{tabular}

Table 8: Trends in built-up areas, greenspace, and selected thermal comfort indices in Abeokuta South

\begin{tabular}{|l|l|l|l|l|l|l|l|}
\hline Year & Built-up area $(\mathrm{Ha})$ & Greenspace $(\mathrm{Ha})$ & $\mathrm{THI}\left({ }^{\circ} \mathrm{C}\right)$ & ET $\left({ }^{\circ} \mathrm{C}\right)$ & PET $\left({ }^{\circ} \mathrm{C}\right)$ & RSI & PMV \\
\hline 1986 & 2785 & 4315 & 25.116 & 24.932 & 24.9 & 0.0919 & 1.1 \\
\hline 2000 & 3826 & 3232 & 25.454 & 25.255 & 24.9 & 0.107 & 1.1 \\
\hline 2018 & 6579 & 301 & 26.192 & 25.961 & 26.1 & 0.141 & 1.3 \\
\hline
\end{tabular}

Table 9: Trends in built-up areas, greenspace, and selected thermal comfort indices Ifo

\begin{tabular}{|l|l|l|l|l|l|l|l|}
\hline Year & Built-up area $(\mathrm{Ha})$ & Greenspace $(\mathrm{Ha})$ & $\mathrm{THI}\left({ }^{\circ} \mathrm{C}\right)$ & $\mathrm{ET}\left({ }^{\circ} \mathrm{C}\right)$ & PET $\left({ }^{\circ} \mathrm{C}\right)$ & RSI & PMV \\
\hline 1986 & 3801 & 48299 & 25.313 & 25.118 & 25 & 0.101 & 1.1 \\
\hline 2000 & 6156 & 45944 & 25.682 & 25.482 & 25 & 0.117 & 1.1 \\
\hline 2018 & 19351 & 32749 & 26.363 & 26.127 & 26.2 & 0.149 & 1.3 \\
\hline
\end{tabular}

Table 10: Trends in built-up areas, greenspace, and selected thermal comfort indices in Shagamu

\begin{tabular}{|l|l|l|l|l|l|l|l|}
\hline Year & Built-up area $(\mathrm{Ha})$ & Greenspace $(\mathrm{Ha})$ & $\mathrm{THI}\left({ }^{\circ} \mathrm{C}\right)$ & $\mathrm{ET}\left({ }^{\circ} \mathrm{C}\right)$ & $\mathrm{PET}\left({ }^{\circ} \mathrm{C}\right)$ & RSI & PMV \\
\hline 1986 & 3157 & 58243 & 25.140 & 24.959 & 24.7 & 0.093 & 1 \\
\hline 2000 & 5079 & 56,321 & 25.526 & 25.332 & 24.7 & 0.110 & 1.1 \\
\hline 2018 & 15554 & 45846 & 26.242 & 26.010 & 26 & 0.143 & 1.3 \\
\hline
\end{tabular}

Table 11: Trends in built-up areas, greenspace, and selected thermal comfort indices in Ijebu East

\begin{tabular}{|l|l|l|l|l|l|l|l|}
\hline Year & Built-up area $(\mathrm{Ha})$ & Greenspace $(\mathrm{Ha})$ & $\mathrm{THI}\left({ }^{\circ} \mathrm{C}\right)$ & $\mathrm{ET}\left({ }^{\circ} \mathrm{C}\right)$ & PET $\left({ }^{\circ} \mathrm{C}\right)$ & RSI & PMV \\
\hline 1986 & 1579 & 221216 & 24.843 & 24.703 & 24.2 & 0.078 & 0.9 \\
\hline 2000 & 2724 & 220081 & 25.174 & 25.015 & 24.1 & 0.093 & 1 \\
\hline 2018 & 2843 & 220019 & 25.901 & 25.702 & 25.5 & 0.127 & 1.2 \\
\hline
\end{tabular}

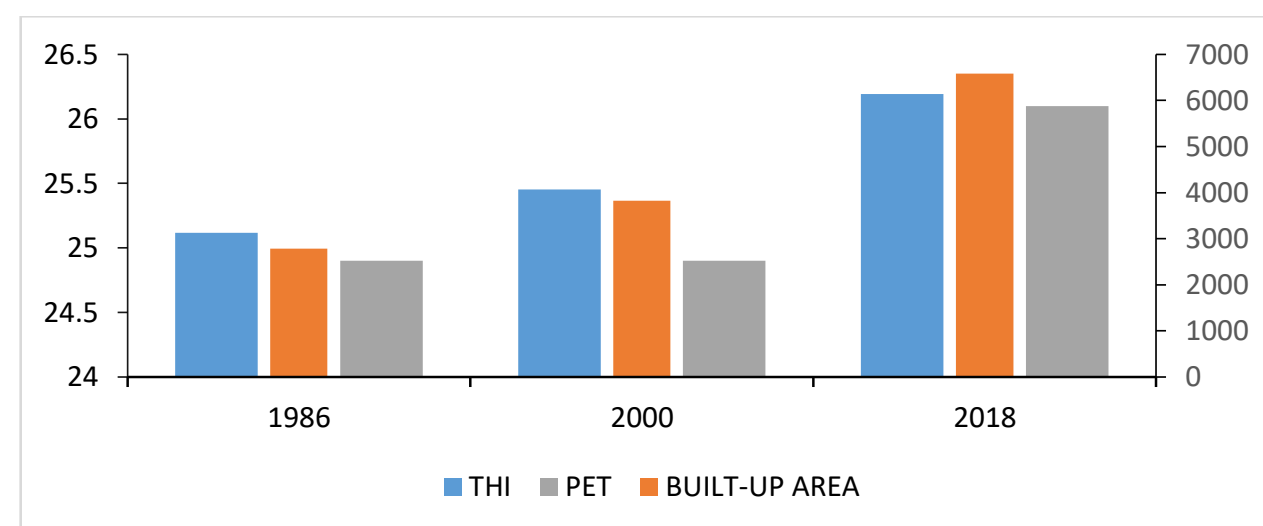

Figure 8a: Trends of THI, PET, and built-up areas in Abeokuta South 


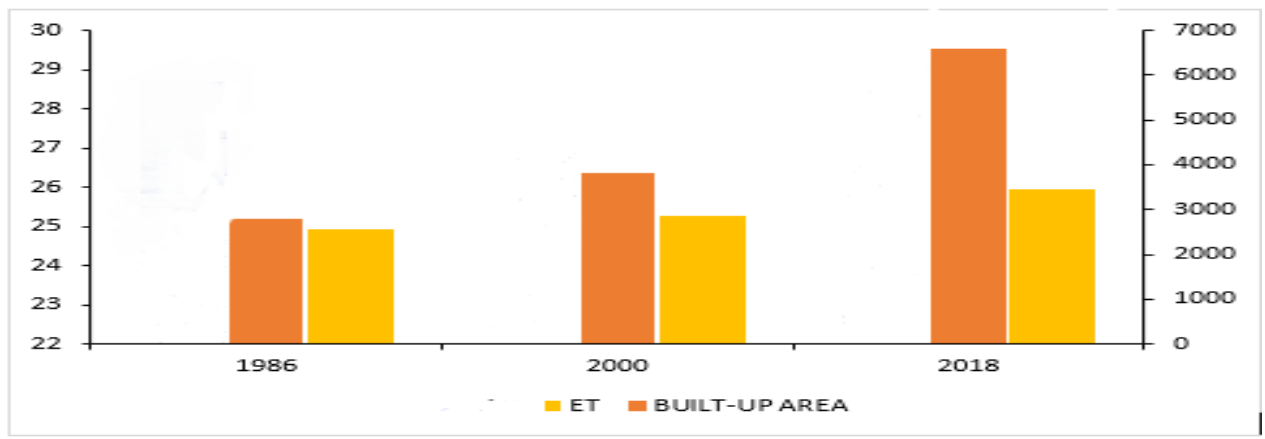

Figure 8b: Trends of ET and built-up areas in Abeokuta South

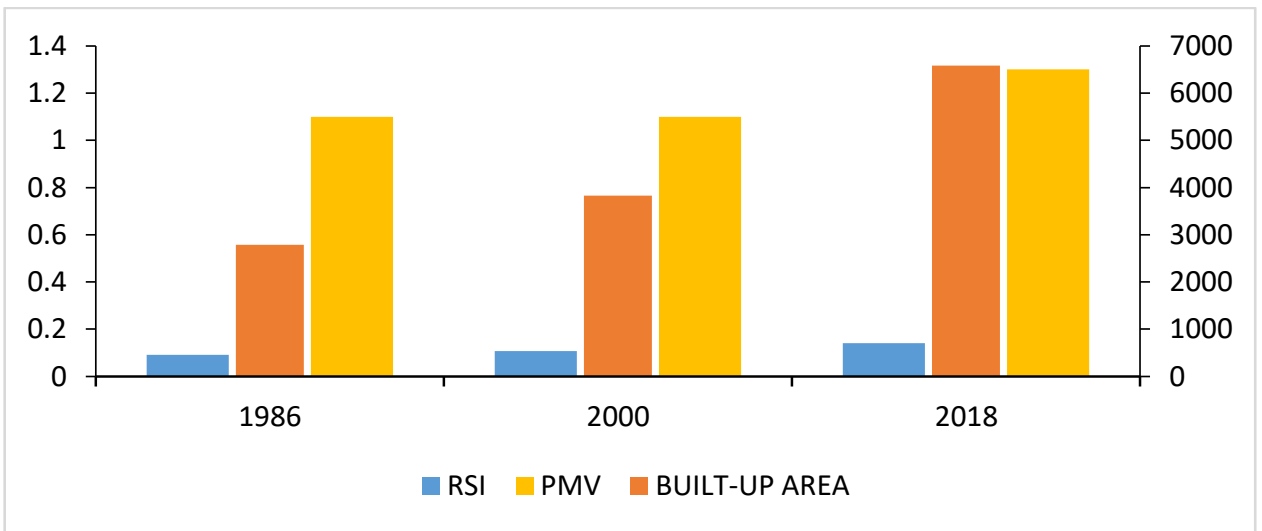

Figure 8c: Trends of RSI, PMV, and built-up areas in Abeokuta South

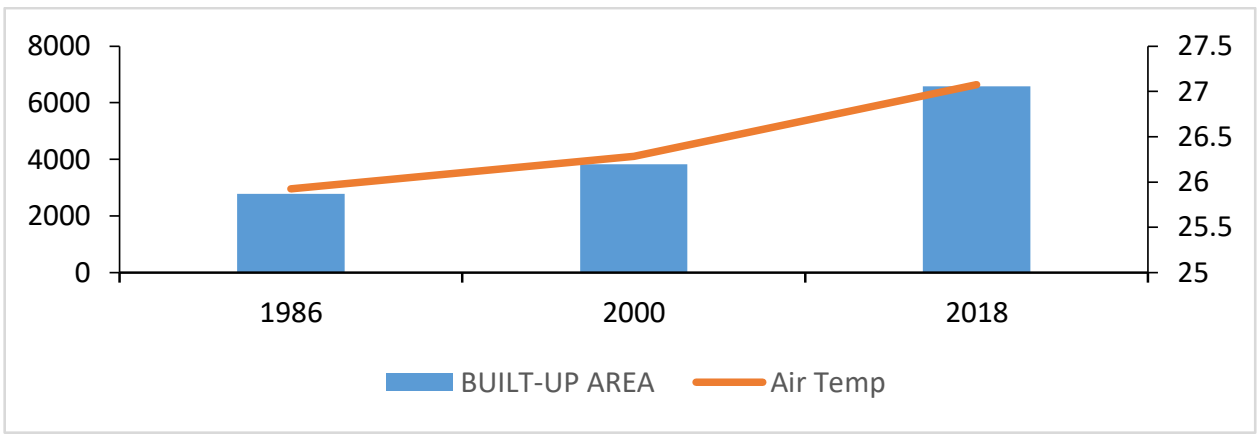

Figure 8d: Trends of air temperature and built-up areas in Abeokuta South

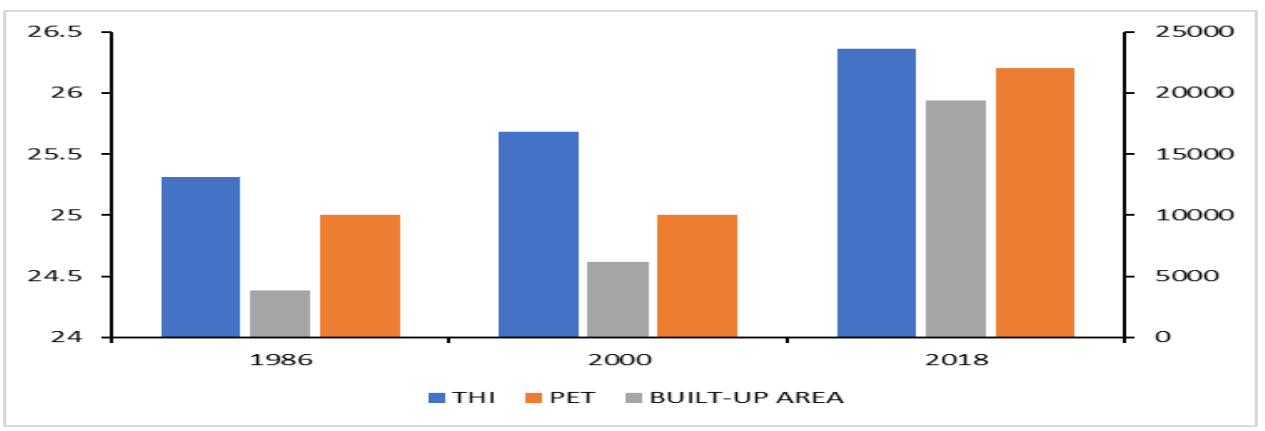

Figure 8e: Trends of THI, PET, and built-up area in Ifo 


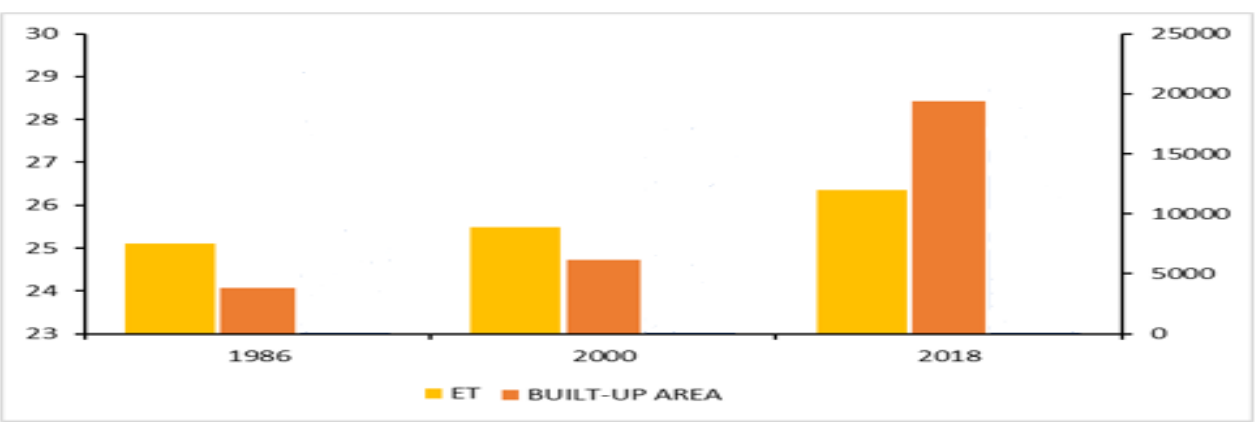

Figure 8f: Trends of ET and built-up areas in Ifo

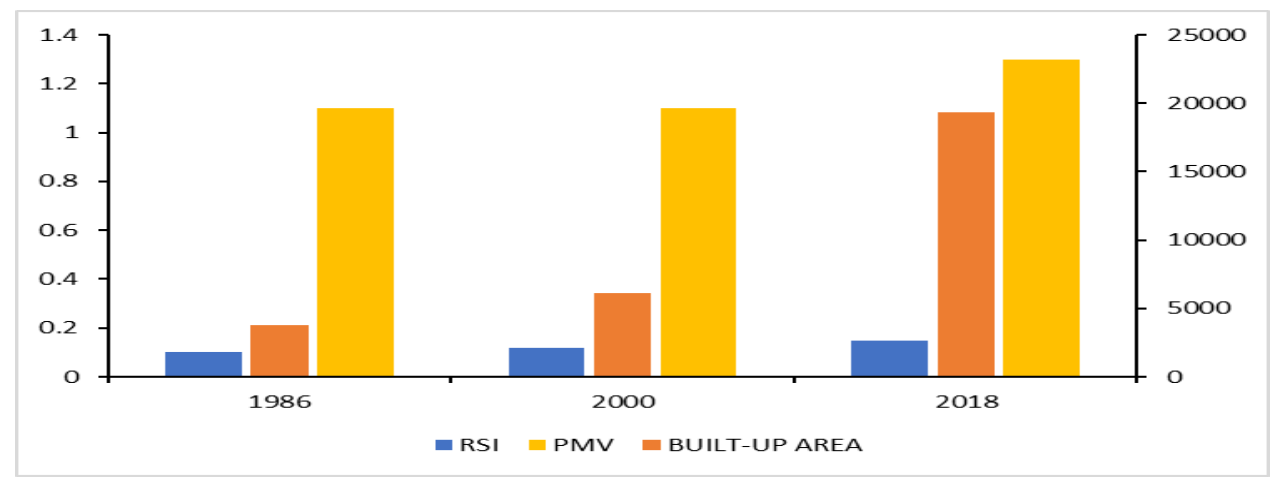

Figure 8g: Trends of RSI, PMV, and built-up areas in Ifo

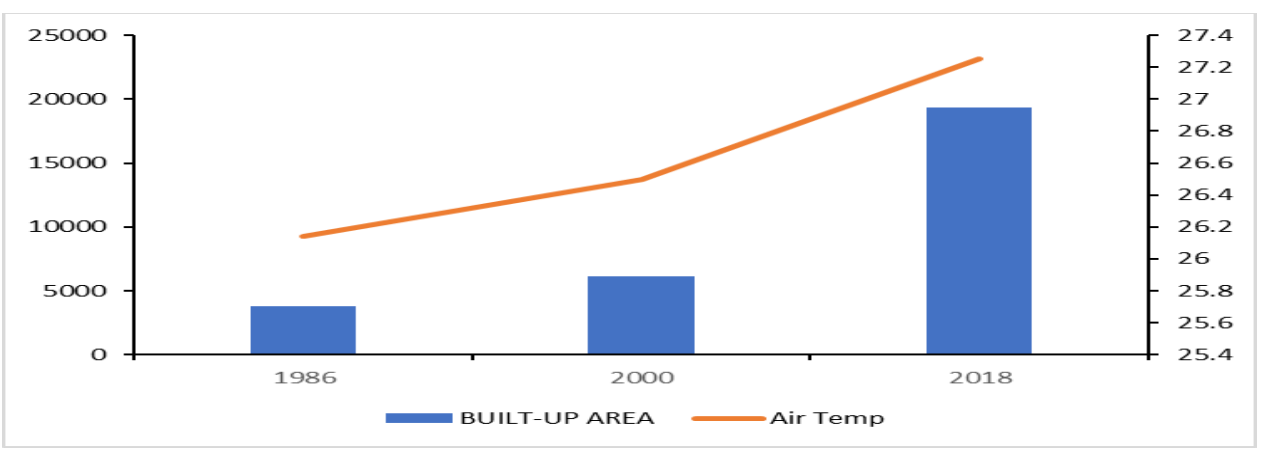

Figure 8h: Trends of air temperature and built-up areas in Ifo

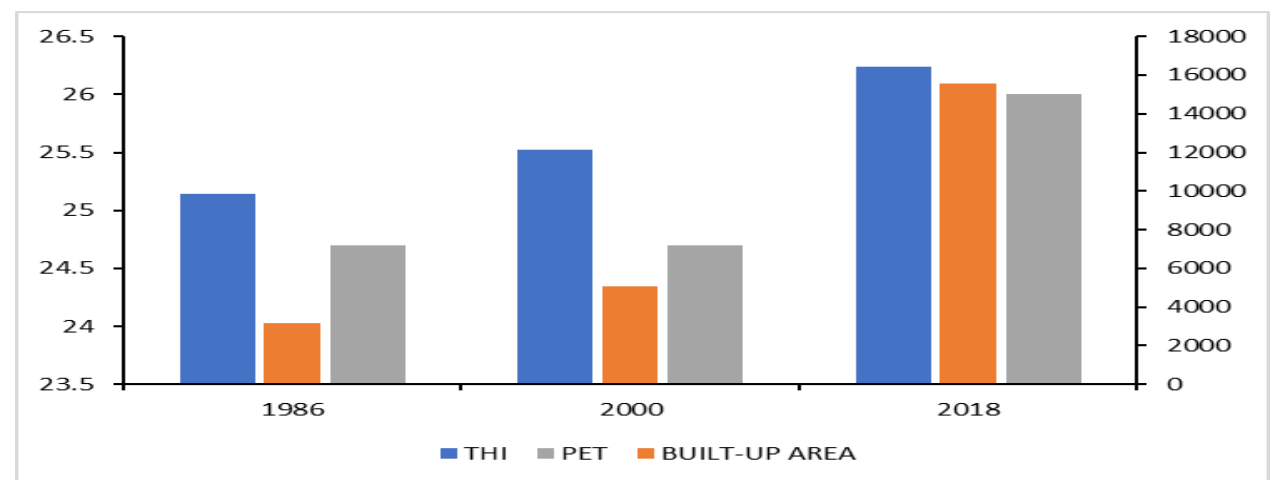

Figure 8i: Chart showing the trends of THI, PET, and built-up area in Shagamu 


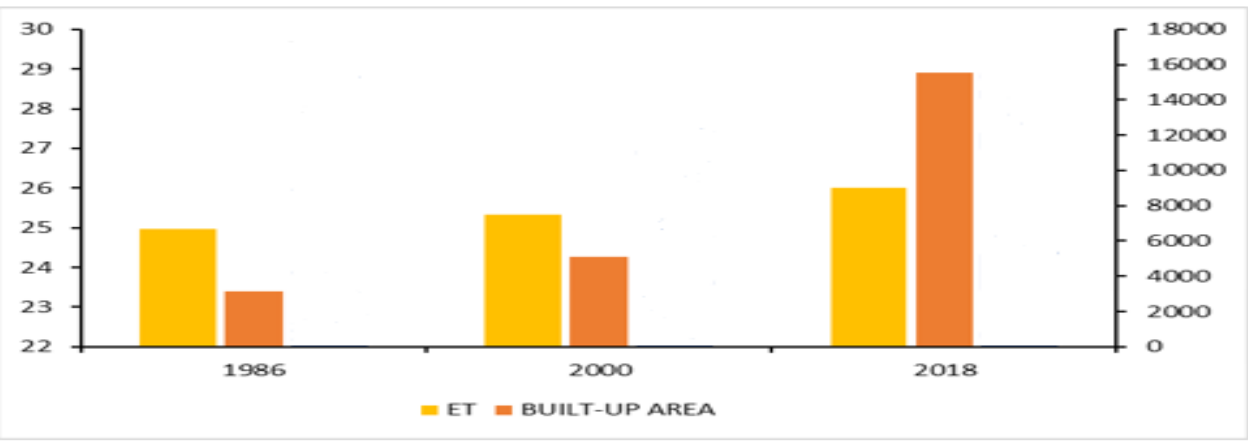

Figure 8j: Trends of ET and built-up areas in Shagamu

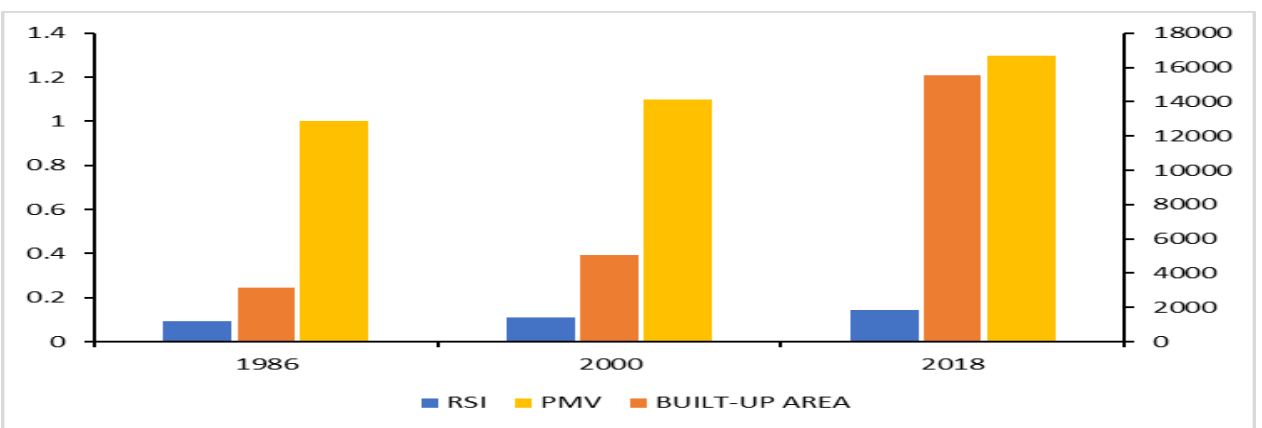

Figure 8k: Trends of RSI, PMV, and built-up areas in Shagamu

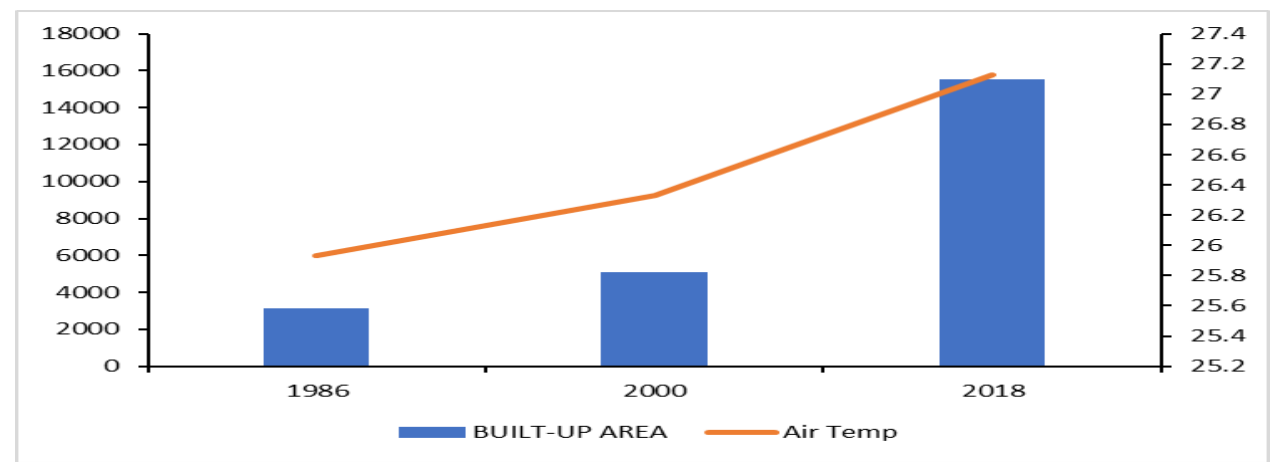

Figure 81: Trends of air temperature and built-up areas in Shagamu

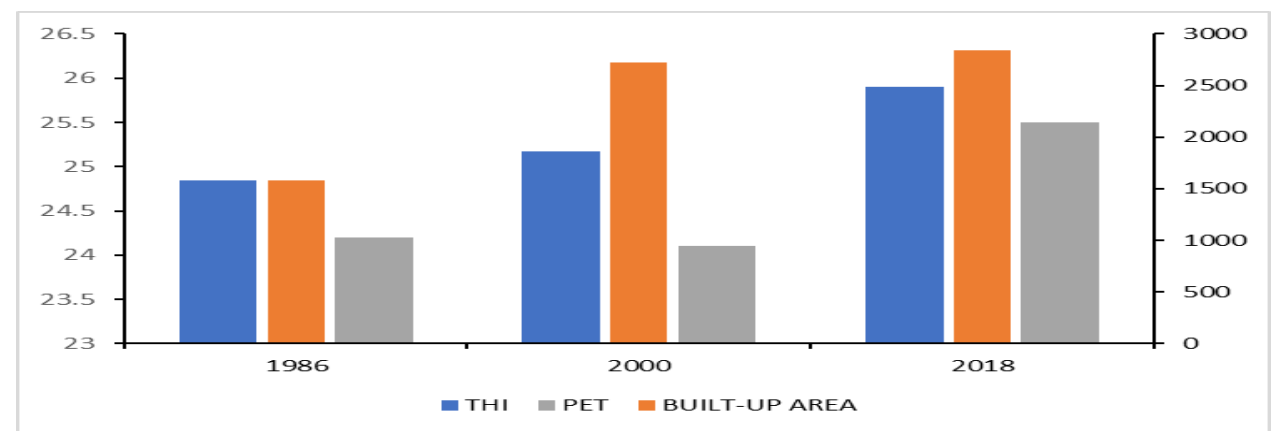

Figure 8m: Trends of THI, PET, and built-up areas in Ijebu East 


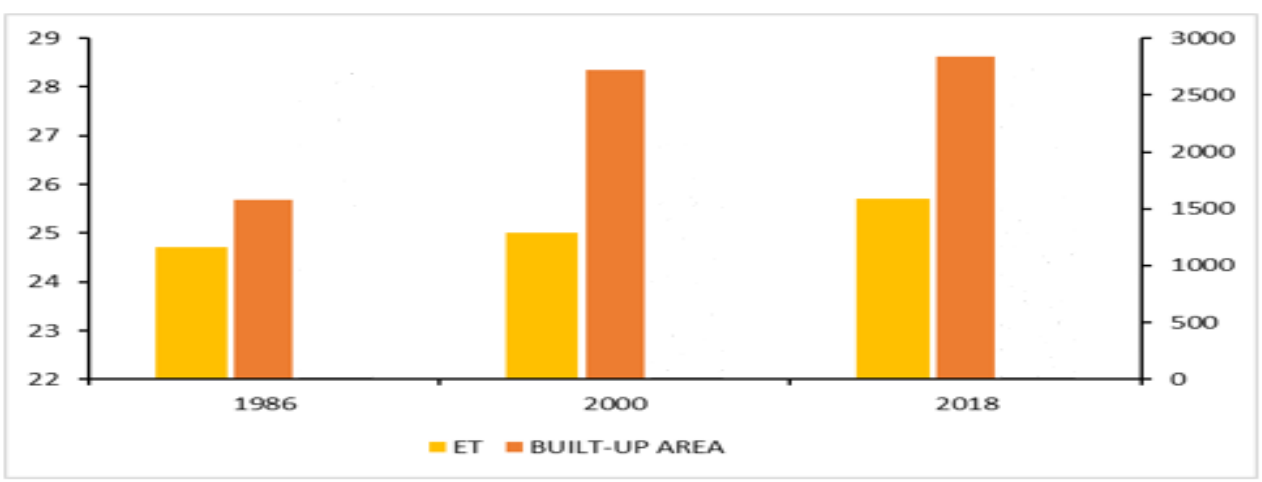

Figure 8n: Trends of ET and built-up areas in Ijebu East

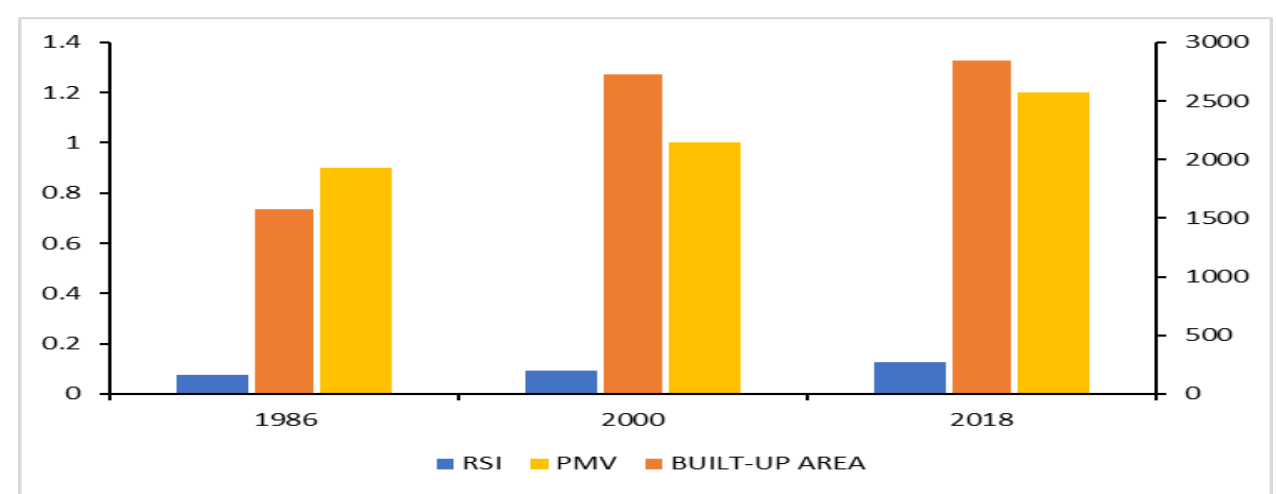

Figure 80: Trends of RSI, PMV, and built-up areas in Ijebu East

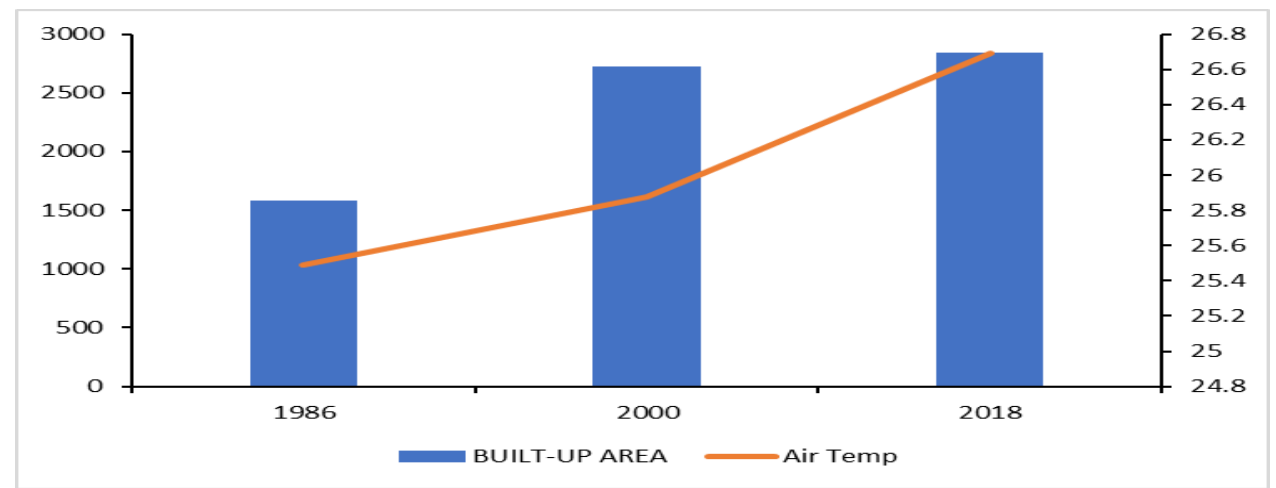

Figure 8p: Trends of air temperature and built-up areas in Ijebu East

\subsection{Conclusions}

This study assessed the impact of urbanization on the outdoor thermal conditions in Abeokuta South, Ifo, Shagamu, Ijebu East. The thermal condition of the four selected local government areas has deteriorated progressively along with increase in built-up areas. The area that's least developed (Ijebu East) was found to be more comfortable than others, while the area with the highest rate of development (Abeokuta south and Ifo LGAs) has the highest level of thermal discomfort.

Heat stress is known to have influence in the mental and physical efficiency of man. In tropical areas like Nigeria, illnesses resulting from extremely high temperatures and excess heat leading to heat stroke, and heat cramps are very common. Hence, the reason why thermal comfortability deserves some close study.

\section{References}

Adebayo, Y. (1991). Day-time effects of urbanization on relative humidity and vapour pressure in tropical city. Theor. Appl. Climatol. 43, pp. 17-30. 
Adelekan, I. O. (2005). Urban climate research in Nigeria. Country Report. Newslett. Int. Assoc. Urban Clim. 13, pp. 8-10.

Ahmed, K.S. (2003). Comfort in urban spaces: Defining the boundaries of outdoor thermal comfort for the tropical urban environments. Energy and Buildings, 35(1), pp. 103-110. doi: 10.1016/S0378$7788(02) 00085-3$

Aina, S. A. (1989). Aspects of the Urban Climate of Oshogbo. Unpublished M.Sc Dissertation, University of Ibadan, Nigeria.

Akinbode, O. M., Eludoyin, A. O. and Fashae, O. A. (2008). Temperature and relative humidity distributions in a medium-size administrative town in southwest Nigeria. J. Environ. Manage. 87, pp. 95-105.

ASHRAE, (2010). Thermal environmental conditions for human occupancy. ASHRAE standard; American Society of Heating, Refrigerating and Air-Conditioning Engineers. Atlanta: ASHRAE.

Ayoade, J. (1978). Spatial and seasonal patterns of physiologic comfort in Nigeria. Theor. Appl. Climatol. 26, pp. 319-337.

Efe, S. I. (2004). Urban Effects on Precipitation Amount and Rainwater Quality in Warri Metropolis, Unpublished PhD thesis, Delta University, Abraka, Nigeria.

Eludoyin, O.M., Adelekan, I.O., Webster, R. and Eludoyin, A.O. (2013). Air temperature, relative humidity, climate regionalization and thermal comfort of Nigeria. Int. J. Climatol., 34, pp. 2000-2018.

Galony, G. S. (1996). Urban design morphology and thermal performance. Atmospheric Environment, 30(3), pp. 455-465.

Höppe, P. (2002). Different aspects of assessing indoor and outdoor thermal comfort. Energy \& Buildings, 34(6), pp. 661-665.

IPCC, (2007). Solomon S, Qin D, Manning M, Chen, Z, Marquis M, Averyt K, Tignor M, Miller H, 2007. IPCC fourth assessment report (AR4). Climate change.

Kyle, W. J. (1992). Summer and winter patterns of human thermal stress in Hong Kong

Markus, T. A. and Morris, E. N. (1980). Buildings, climate and energy. London: Pitman

Massetti, L., Petralli, M. and Brandani, G. (2019). Modelling the effect of urban design on thermal comfort and air quality: The SMART Urban Project. Build. Simul. 12, pp. 169-175.

Matzarakis, A., Rutz, F. and Mayer, H. (2007). Modelling radiation fluxes in simple \& complex environments - application of the Rayman model. Int. J. Biometeorol. 51, pp. 323-334.

$\mathrm{Ng}$, E. (2012). Towards planning and practical understanding of the need for meteorological and climatic information in the design of high-density cities: A case-based study of Hong Kong. Int. J. Climatol. 32, pp. 582-598.

Nieuwolt S. Tropical climatology. London: Wiley; 1977.

Njoroge, J.B.M., Nda'Nganga, K., Wariara, K. and Maina, M.G. (2011). Characterising changes in urban landscape of Nairobi city, Kenya. Acta Horticulturae, 911, pp. 537-543.

Ogunsote, O. O. and Ogunsote, B. P. (2003). Choice of a thermal index for architectural design with climate in Nigeria. Habitat International, 27, pp. 63-81. 
Ogunsote, O. O. and Prucnal-Ogunsote, B. (2007). Extreme Weather and Climate Events: Implications for Urban Planning, Architecture and Tourism Infrastructure in Nigeria. Federal University of Technology, Akure.

Olaniran, O. J. (1982). The Physiological Climate of Ilorin, Nigeria. Arch. Met. Geoph. Biokl. Ser. B, 31, pp. 287-299.

Omogbai, B.E. (1985). Aspects of Urban Climate of Benin City. Unpublished M.Sc. Dissertation, University of Ibadan, Nigeria.

Omonijo, A. G. and Matzarakis, A. (2011). Climate and bioclimate analysis of Ondo State. Meteorologische Zeitschrift, 20(5), pp. 531-539.

Oniarah, A. (1990). Aspects of urban Climate of Benin City. Unpublished M.Sc Dissertation University of Ibadan, Nigeria.

Polydoros, T. and Cartalis, C. (2014). Assessing Thermal Risk in Urban Areas - an Application for the Urban Agglomeration of Athens. Advances in Building Energy Research, 8(1), pp. 74-83.

Quang-Van Doan, Hiroyuki Kusaka, and Quoc-Bang Ho, (2016). Impact of future urbanization on temperature and thermal comfort index in a developing tropical city: Ho Chi Minh City. Urban Climate, 17, pp. 20-31.

Robaa (2011). Effect of Urbanization and Industrialization Processes on Outdoor Thermal Human Comfort in Egypt. Atmospheric and Climate Sciences, 1, pp. 100-112. doi:10.4236/acs.2011.13012

Unger, J. (1999). Comparisons of urban \& rural bioclimatological conditions in the case of a CentralEuropean city. Int. J. Biometeorol 43, 139. doi: 10.1007/s004840050129.

United Nations Population Division (2012), World Urbanization Prospects: The 2011 Revision, POP/DB/WUP/Rev.2007, United Nations Department of Economic and Social Affairs, New York.

Xiong, Y., Huang, S., Chen, F., Ye, H., Wang, C. and Zhu, C. (2012). The Impacts of Rapid Urbanization on the Thermal Environment: A Remote Sensing Study of Guangzhou, South China. Remote Sens. 4, pp. 2033-2056. doi:10.3390/rs4072033

Yang, B., Yang, X., Leung, L. R., Zhong, S., Qian, Y., Zhao, C., et al. (2019). Modelling the impacts of urbanization on summer thermal comfort: the role of urban land use and anthropogenic heat. $J$. Geophys. Res. Atmos. 124, pp. 6681-6697. 